\title{
ANGELO PRINCIPE
}

\section{CENTRING THE PERIPHERY. PRELIMINARY NOTES ON THE ITALIAN CANADIAN}

PRESS: $1950-1990$

\section{The Radical Press}

From the end of the Second World War to the 1980s, eleven Italian Canadian radical periodicals were published: seven left-wing and four rightwing, all but one in Toronto. ${ }^{1}$ The left-wing publications were: Il lavoratore (the Worker), La parola (the Word), La carota (the Carrot), Forze nuove (New Forces), Avanti! Canada (Forward! Canada), Lotta unitaria (United Struggle), and Nuovo mondo (New World). The right-wing newspapers were: Rivolta ideale (Ideal Revolt), Tradizione (Tradition), Il faro (the Lighthouse or Beacon), and Occidente (the West or Western civilization).

Reading these newspapers today, one gets the impression that they were written in a remote era. The socio-political reality that generated these publications has been radically altered on both sides of the ocean. As a consequence of the recent disintegration of the communist system, which ended over seventy years of East/West confrontational tension, in Italy the party system to which these newspapers refer no longer exists. Parties bearing new names and advancing new policies have replaced the older ones, marking what is now considered the passage from the first to the second Republic. ${ }^{2}$ As a result, the articles on, or about, Italian politics published

${ }^{1}$ I would like to thank several people who helped in different ways with this paper. Namely: Nivo Angelone, Roberto Bandiera, Damiano Berlingieri, Domenico Capotorto, Mario Ciccoritti, Elio Costa, Celestino De Iuliis, Odoardo Di Santo, Franca Iacovetta, Teresa Manduca, Severino Martelluzzi, Roberto Perin, Concetta V. Principe, Guido Pugliese, Olga Zorzi Pugliese, and Gabriele Scardellato. And, finally, I extend my thanks to Dan Iannuzzi, President of Deison Press, for allowing meto have access to the archive of his publications, Corriere canadese and Corriere illustrato.

${ }^{2}$ For example, on the left, the strong, monolithic Italian Communist Party has a new name, Partito dei democratici di sinistra (DS); and, more importantly, it has a democratic structure and a reformist political platform. Two smaller splinter parties, Rifondazione comunista (RC) and Comunisti democratici italiani (Cl), 
in the newspapers in question have no reference at all to the present political nomenclature.

Although the Italian Canadian radical periodicals do not refer to the new political nomenclature, their pages reflect, perhaps better than the widely circulating commercial newspapers such as Corriere canadese, the double process that occurred in Italy and among the local Italian communities in the years in question. The constant evolution in the Italian political landscape inside and outside the political parties gave rise to debates, conflicts, and divisions among the Italian Canadian militants, leading to

still allude to a defunct era. Even the neo fascist MSI (Movimento Sociale Italiano), the ideological and political heir of the second Fascism (the Fascism which dominated Mussolini's Repubblica sociale italiana [RSI] of Salò, from September 1943 to April 1945) has changed its name and repudiated its past. In the Congress of Fiuggi (1995), its leader Gianfranco Fini, a smooth and shrewd politician, had the party's name changed to Alleanza nazionale (AN) and turned the page on old and new fascism and its "infamous" anti-Semitism. He went so far as to state that "antifascism was an essential moment historically for the return of democracy in Italy;" and in his 2003 state visit to Israel, deputy Prime Minister Fini courageously stated that the RSI was a negative experience and defined Fascism as an "absolute evil." These changes have led the ex-neo-fascists from the isolation in which they had been confined since 1960 to both centreright governments of Premier Silvio Berlusconi of our day.

In the political centre, under the scrutiny of the judicial inquest "Mani pulite" (clean hands) on the collusion between government and business, the once glorious Socialist Party dissolved; and so did the largest Italian Party, Democrazia cristiana, which was sarcastically referred to as "la balena" (the whale), alluding to its electoral strength. From their ashes new parties have emerged: Forza Italia (FI), led by the media tycoon Silvio Berlusconi, the UDC (Unione democratici cristiani), leaning to the right; and the Partito della margherita (PM), leaning to the left.

Moreover, from the crisis of the first Italian Republic, two brand-new parties have been founded: the strong Lega nord (Northern League) of Umberto Bossi; and the small party Italia dei valori of the ex-magistrate Antonio Di Pietro. Bossi and his Lega nord (LN) postulate an ambiguous policy, a mesh of succession, federalism, fiscal autonomy, and a good dose of racism, while Italia dei valori continues the ethical battle that its leader Di Pietro, a Magistrate of "Mani pulite", had waged against corruption. Although the Italian political landscape has always been crowded with a myriad of local parties, as a result of all these changes from 1994 to the present, Italy today is dominated by two political coalitions: the centre-right Casa della libertà (Home of freedom), grouping FI and its three smaller allies, AN, LN, and UDC; and the center-left Ulino (Olive tree), grouping DS, PM, Green Party, Socialists and others. 
changes in political and ideological orientations: different ideological positions led to the succession of one newspaper by another and, in the case of the local communists, caused the parallel publication of two periodicals that represented opposing political lines.

Within the local Italian communities, moreover, it is evident that the interest of some of these publications shifted from carrying predominantly Italian news and reports to stressing local community and Canadian content, even using English in order to reach second generation Canadianborn Italians. This is particularly true of the left-wing newspapers, although even the right-wing publications registered a shift from abstract, theoretical questions to relevant political issues of the day and eventually turned to the use of English, as we shall see below.

\section{Left-wing papers ${ }^{3}$}

From the second half of the 1940s and throughout the 1950s and ' 60 s, the Italian population in Canada swelled by almost seven hundred per cent as the following table shows:

\begin{tabular}{|l|r|r|r|r|}
\hline & 1941 & 1951 & 1961 & 1971 \\
\hline Italian origin & 112,625 & 152,245 & 450,351 & 730,82 \\
\hline Mother tongue Italian & 80,269 & 92,244 & 339,626 & 538,360 \\
\hline
\end{tabular}

In 1971, over $59 \%$ of the Italian population in Canada or 432,425 was concentrated in the Metropolitan city of Toronto: 271,755 were in the Toronto city core and the rest in the surrounding townships: York West 41,665, York East 6,545, Etobicoke 23,480, North York 73,495 and Scarborough 15,485.4 Emigration from Italy slowed down considerably after 1971.

Most immigrants from Italy were agricultural workers and tradespeople displaced from a rural economy that was in shambles after the devasta-

${ }^{3}$ The reader must be aware of the ongoing debate on the validity of the dichotomy of left and right in describing today's politics since the political platforms of the many contending parties inevitably invade each other's territory. However, Noberto Bobbio (Destra e sinistra, pp. 7-8) is right when he argues that the distinction between right and left does not exclude at all the configuration of an interrupted line from extreme left to extreme right or vice versa that is the same thing, implying the existence of many shades of right and many shades of left. In our case, furthermore, the distinction between left and right is marked on different levels: ideological, political, and practical.

${ }^{4}$ For the figures regarding Canada see Historical Statistics of Canada, A125-163 and A185-237; for the Toronto Italian population see, Census Tract Bulletin, $1971,2,16,18,26$, and 32 . 
tion of the Second World War. A survey of 100 Italian men conducted by the International Institute of Metropolitan Toronto (IIMT) in the years 1962-64 reveals that, before emigrating, 43 of the 100 men surveyed had worked in agriculture, 29 had been construction workers, and 7 had been general labourers. The remaining 22 men had practised a variety of trades as barbers, bakers, tailors, and cabinetmakers. ${ }^{5}$

Moreover, the formal education of those surveyed was well below Canadian standards. Not all Italian immigrants had completed the fiveyear basic schooling program that was the norm in Italy until 1955; in fact, some older men and women had no schooling at all. ${ }^{6}$ Because of their limited education and lack of proficiency in English, most Italians were engaged in difficult and dangerous jobs in the construction industry and provided other type of manual labour for which they were paid much less than the going rates. Unscrupulous employers exploited them, cheating them of their vacation-pay, unemployment insurance stamps, and hours of pay, and some employers even demanded as a condition for employment a portion of the pay cheque in the form of a kickback. This was particularly prevalent in the construction industry. ${ }^{7}$ Pierre Berton, journalist and historian, described the terrible conditions in which most Italian workers lived in the 1960s in a series of three articles published by the Toronto Star. In summing up his articles he wrote:

The Italians are walled off from the rest of us, partly by language, partly by cultural background, partly by the terrible struggle to survive which leaves them time for very little-but also because the government and the various social agencies have shown little real inclination to reach out to them ... Nor have the wealthy Italian contractors, so eager to exploit their own countrymen, done much for the Italian community. ${ }^{8}$

${ }^{5}$ Ferguson, Newcomers in Transition, 44-45.

${ }^{6}$ The table below (Ferguson, Newcomers in Transition, 41, Table 18) shows the education levels of Italian immigrants.

\begin{tabular}{|l|c|c|c|c|c|c|c|}
\hline & 5 + years & 5 years & 4 years & 3 years & 2 years & 1 year & none \\
\hline 100 men & 9 & 47 & 19 & 7 & 6 & 0 & 5 \\
\hline 100 women & 5 & 26 & 16 & 11 & 7 & 1 & 12 \\
\hline
\end{tabular}

(Information was not available for 7 men and 22 women)

${ }^{7}$ See Principe, "Two Years of Social Unrest; in Toppan, The Voice of Labor; Colantonio, From the Ground Up; Iacovetta, Such Hardworking People; Proceeding and report (Goldenberg Report).

${ }^{8}$ Berton, "How Italian Live." 
The exploitation of Italian immigrant workers was so widespread and well known that it seems inconceivable that the commercial media serving the Italian community were not aware of it. The media, however, never attempted to make Italian workers aware of their rights, nor was resistance against exploitation encouraged. Frightened by the paranoid witch- hunt unleashed by American Senator McCarthy's "Inquiry on Un-American Activities" which still lingered in the community, Italian Canadian leaders considered every voice speaking about workers' problems and against the status quo to be inspired by communists. The media, in turn, served as ideological mirrors and voices of the community leaders. Such was the context in which the early Italian Canadian left-wing radical publications were conceived and generated.

The first political paper to appear in Toronto after the Second World War was Il lavoratore. Through its title the editors intended to link it with the pre-war homonymous socialist paper published in Toronto in 1936$37.9^{9}$ A group of newcomers, socialists, and communists of the Antonio Gramsci Club appalled at the way in which the community mass media dealt with workers' issues, founded the new Il lavoratore and established a collective editorial board consisting of Jack Capitanio, Tommaso D'Ambrogio, Matteo Federico, Michele Gallo (who created the masthead), Remigio Peghin, Franco Ranieri, Bruno Tutino, Ernesto Valentini, myself, and few others. Il lavoratore was a class-conscious paper and, in some ways, a sectarian and moderate one at the same time. It was sectarian in so far as it was directed to manual workers only; but its political platform was moderate. It encouraged workers to become interested in social issues and in the union movement.

From its first issue, Il lavoratore firmly made two points. "Before you begin to read this newspaper," the first editorial reads, "we would like to say something confidentially: look at your hands. If they are the hands of an honest worker [...], if you have calloused hands, keep on reading it. This is your paper." Then, having warned its readers, and Italian Canadian workers in general, not to fall into the trap of patriotic nostalgia-a sentiment that was fostered by the community commercial media-the editorial continued:

Workers [...] should take interest in the [...] problems related to their jobs. They should discuss them, analyse them factually and then express their opinion honestly and without fear. Whatever their opinion might be, it is preferable to mental castration or to a lie that sinks man to the level of beasts

9Principe, "The Italo-Canadian Anti-Fascist Press," 127-131. 


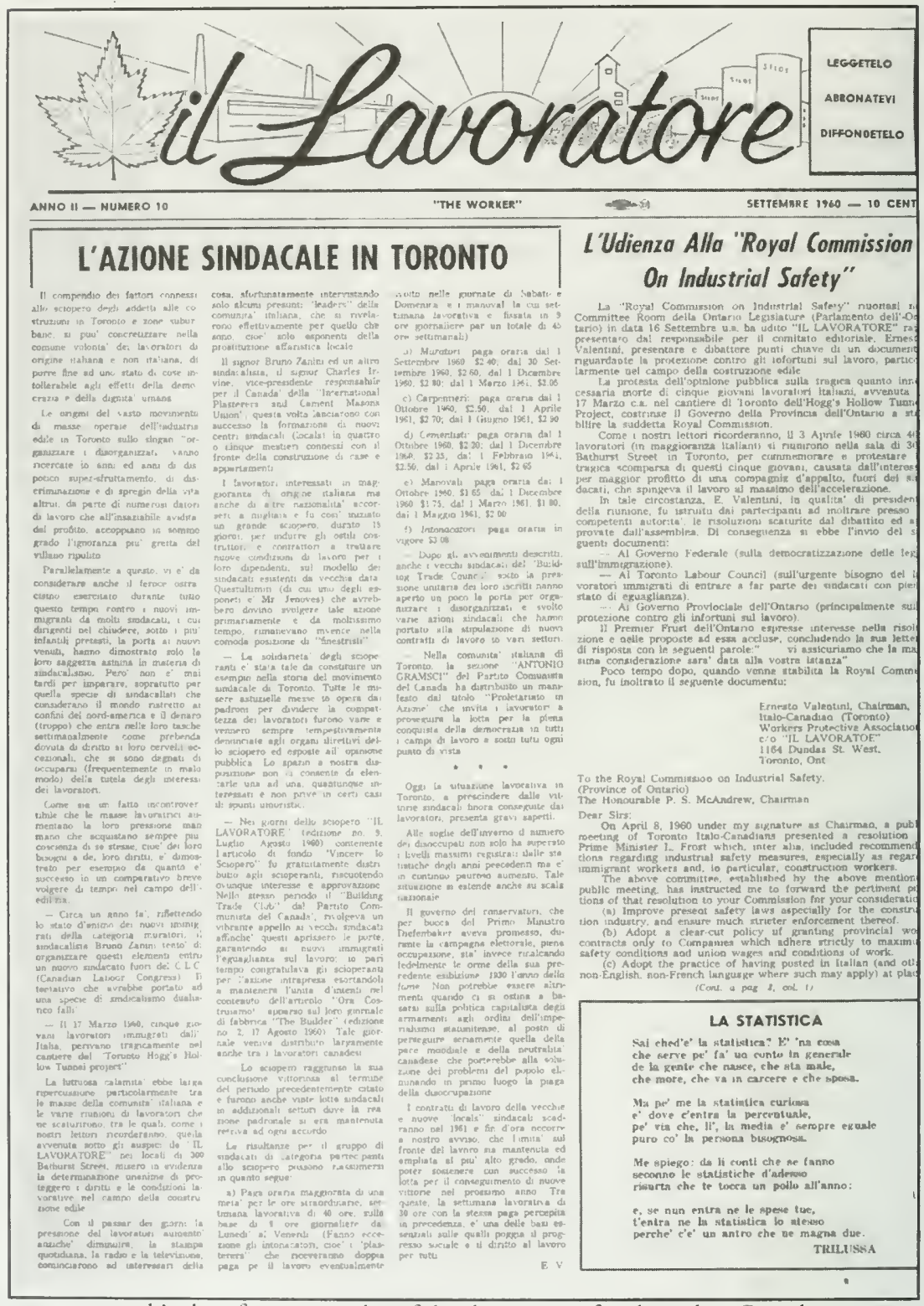

and is therefore unworthy of the democratic freedom that Canada grants to everybody. ${ }^{10}$ [Translations mine unless otherwise indicated.]

As a paper published by socialists and communists, Il lavoratore did not align itself politically with the democratic socialist Canadian 
Commonwealth Federation (CCF) to which the socialists leaned, or to the Canadian Progressive Party (the communist party) to which the Gramsci Club belonged. However, it expounded a policy in defence of manual workers in general, explaining the role and functions of labour unions in society, and defending Italians against discrimination and exploitation. With its stand against the status quo, Il lavoratore may have anticipated the construction workers' militancy, which led to the formation of the Brandon Union Group and the strikes of 1960 and 1961, the two most militant and, at times, even violent strikes of the post-war labour movement in the construction industry in Toronto. These strikes prompted Toronto's daily newspapers, the Globe and Mail, the Toronto Daily Star, and the Telegram in particular, to switch their interest from national issues to the problems of the humble Italian construction workers. They exposed case after case of exploitation, abuse, and maltreatment to which nonunionised workers were subjected in the construction industry. ${ }^{11}$

Accidents on the job were common events in the 1950s and ' 60 s. Il lavoratore spoke loudly against what its editors considered a general lack of interest by unions, government, and the public. When, on 17 March 1960, five men (Guido Mantella, Alessandro Mantella, John Correglio, John Fusillo and Pasquale Allegrezza) died in the collapse of the Hogg's Hollow tunnel while working on the construction of the Yonge Street Subway, Il lavoratore published the following editorial:

On the construction sites, heaps of crosses indicate the price Italian workers have paid so that some contractors can build their fortunes rapidly. The Yonge Street accident is the last straw.

Many Italians, too many die on the job. Every time an accident occurs there is an investigation which, when it is not a palliative, leaves things as they are. Even this time they say there will be one to discover who is ultimately responsible. And to what end? The real issue is not to vindicate those five men by charging one or more responsible individuals.

The real question is much more serious. It is time to provide safery on the job to the thousands of working men who, judging by the daily accidents and deaths, risk their lives for a meagre wage every day. Therefore, there is no point in pretending to do something by calling for an inquiry and then closing the case. There is a need for strict new laws against those contractors who do not implement every necessary measure to prevent accidents on the job. And every time one is found guilty he should be

${ }^{11}$ Iacovetta, Such Hardworking People, 154-196; Principe, "Two Years of Social Unrest," 9-11; Colantonio, From the Ground Up, 94-113 and 121-148; Toppan, The Voice of Labor, 55-58. 
punished with the full force of the law to make him and those like him understand that no one is above the law. ${ }^{12}$

Moving from the editorial to action, Il lavoratore organized a public meeting on 3 April 1960 to commemorate and protest the tragic deaths at Hogg's Hollow. At the heated meeting a resolution was passed and sent to the Premier of Ontario, Leslie Frost, and a Workers' committee was elected to pursue the matter. Part of that resolution was also mailed to the Honourable P.S. McAndrew, who chaired the Royal Commission on Industrial Safety. It made six recommendations:

1) Improve present Safety Laws $[\ldots]$ and insure much stricter enforcement thereof.

2) Improve and strengthen the enforcement of provincial laws on Minimum Wages, Vacation Pay, Transportation to and from Work, Sanitary Facilities, Hours of Work Act, etc...

3) [Grant] provincial work contracts only to Companies, which adhere strictly to maximum safety conditions and union wages...

4) Amend the Fair Employment Practices Act to guaranty no discrimination for political adherence or union activities ...

5) Adopt practice of having posted in Italian (and other non-English, nonFrench languages) ... pertinent labour legislation and Safety regulations ...

6) Make it obligatory for Safety Inspectors ... [to] be proficient in [other languages], or have interpreters with them when covering industries where a considerable section of employees are non-English speaking. ${ }^{13}$

Upon receiving the brief, the Commission Chairman invited the president of the Workers' committee, Ernesto Valentini, to attend one of the Commission hearings. Il lavoratore was, moreover, probably the only Italian Canadian newspaper to expound a policy of salary equity for women in the 1950s and '60s. It advocated that, "Unions must consider the problem of equal salary for women in all sectors of industry a task of primary importance. They must enforce this in each plant and factory." 14

For the first issues, Il lavoratore was a very modest publication of 12 magazine-size pages; in 1960 it became a four-page tabloid. In its modest dress, it had a circulation of over 1,000 copies, a notable success for the time, considering the means then at the disposal of the publishers: 250 copies were sent to Montreal, Quebec, 100 copies to British Columbia, some to the Niagara peninsula and other Ontario towns, and over 500

\footnotetext{
12 Il lavoratore (March 1960): 1.

13 Il lavoratore (September 1960): 1-2.

14 Il lavoratore (November 1959): 8.
} 
copies were distributed in Toronto. In the cold war atmosphere, the paper, with its anti status quo stance, was like a breath of fresh air in a stale atmosphere. However, it alarmed the prominent leaders of the Italian community: the Corriere canadese attacked it; priests excommunicated it; the Italian consular authorities kept it at bay; and the Royal Canadian Mounted Police ( RCMP) kept the editors under surveillance.

On 18 April 1959 the Corriere canadese wrote: "For about two years in Toronto, it was rumoured that a communist paper in Italian was going to be published [...] after long and secret preparations, last week some hundred copies of a newspaper that calls itself Il lavoratore were distributed [...] The comrades however remained within the law." At least one priest of St. Agnes Church warned some of his parishioners of the danger that the communist paper posed to young people. The Italian Consulate blacklisted the editors. And several persons who were involved with Il lavoratore, including the author of this article, were denied Canadian citizenship until the Citizenship Act was amended in 1969.15

These hostile conditions, along with the conflicting viewpoints of the socialists and communists on the editorial board of the paper, made every issue a struggle and brought about the demise of Il lavoratore at the end of 1961. This local ideological conflict coincided with the creation of the centre-left government of the Christian Democracy and the Italian Socialist Party in Italy, which marked the diverging policy of the two working class parties, the communists and socialists. The same year, the creation in Canada of the New Democratic Party (NDP) induced the nucleus of Italian socialists who had been involved with Il lavoratore to organize themselves in the Associazione Democratica Italo-canadese (ADI) in competition with the above-mentioned communist Gramsci club. This nucleus soon grew to over one hundred persons. Their task was to establish the new party in the Italian community. Patiently and with years of involvement in the community and in several provincial and federal elections and bi-elections, they contributed significantly to the creation of the conditions which led to the election of four Italian Canadian NDP members in the 1975 Ontario election as we will see.

The socialists' first step to making the NDP known in the community was the publication of La parola, a modest sixteen-page, magazine-size monthly bulletin, with a circulation of about 400 , mostly in Toronto. Its editorial board consisted of Sandra Gourley (a social worker), Rocco Mastrangelo (a teacher), Giuseppe Mazzotta (a student), Giovanni 
Sinicropi (a professor of Italian literature at the University of Toronto), and myself (editor). The first issue appeared in May 1963. The importance of the paper lies in the fact that it presented overtly socialist ideas in the community, which had been conditioned to fear the word "socialism." It also discussed workers' issues that were ignored or downplayed by the dominant Corriere canadese, which at that time unofficially supported the Progressive Conservative Party. ${ }^{16}$ Presenting their objective, the Italian socialist supporters of the NDP wrote,

Italian workers should organize themselves [...] in defence of their rights [...] by accepting the platform of the New Democratic Party. [...] A government program of social reforms as we want it, and with us the true majority of the country, should be seen neither as concessions, nor as the result of progress, platonically intended. But, more concretely, the reforms should be considered as workers' rightful conquests. ${ }^{17}$

In addition to news and articles on the various facets of NDP policy and on the ADI's organizational drive, La parola discussed different aspects of the Italian community's economic, social, and cultural life. The serious issues most often discussed were the endemic problems: accidents on the job and the protection of construction workers. La parola urged citizens, unions, and government to address and find a solution for these issues. Echoing an editorial that had been published in Il lavoratore five years before, La parola wrote:

In spite of the oral commitment of the Minister of Labour and his Ministry assistant, this year [1963], more than any other year, there has been a very high number of fatal accidents on construction sites: 53 . In addition to the loss of 53 lives, accidents have sent hundreds of our conationals to hospitals with broken backs.

The lives of those 53 workers demand that this gangrenous problem be solved [...] now. It is time for Magistrates to speak with the authority of Justice, and to say no loudly to this criminal shame! [...] It is imperative that we open our eyes to the fact that people die daily. [...] We do not want to soil rubble with our brains and blood nor to have our heart squeezed against a brick. The time to vent our rage is now. ${ }^{18}$

${ }^{16}$ In the early 1960 s, three elected conservatives were regular collaborators of the paper: Quinto Marrino, MP for Hamilton; Alan Grossman, MPP for Belwoods in Toronto; and Joe Piccinini, Toronto councilor. In the 1965 Federal Election, Dan Iannuzzi, editor of the paper, was the Progressive Conservative candidate in the Davenport riding in Toronto.

${ }^{17}$ La parola 1:7 (Nov. 1963):3.

${ }^{18}$ La parola 1:6 (1963): 3. 


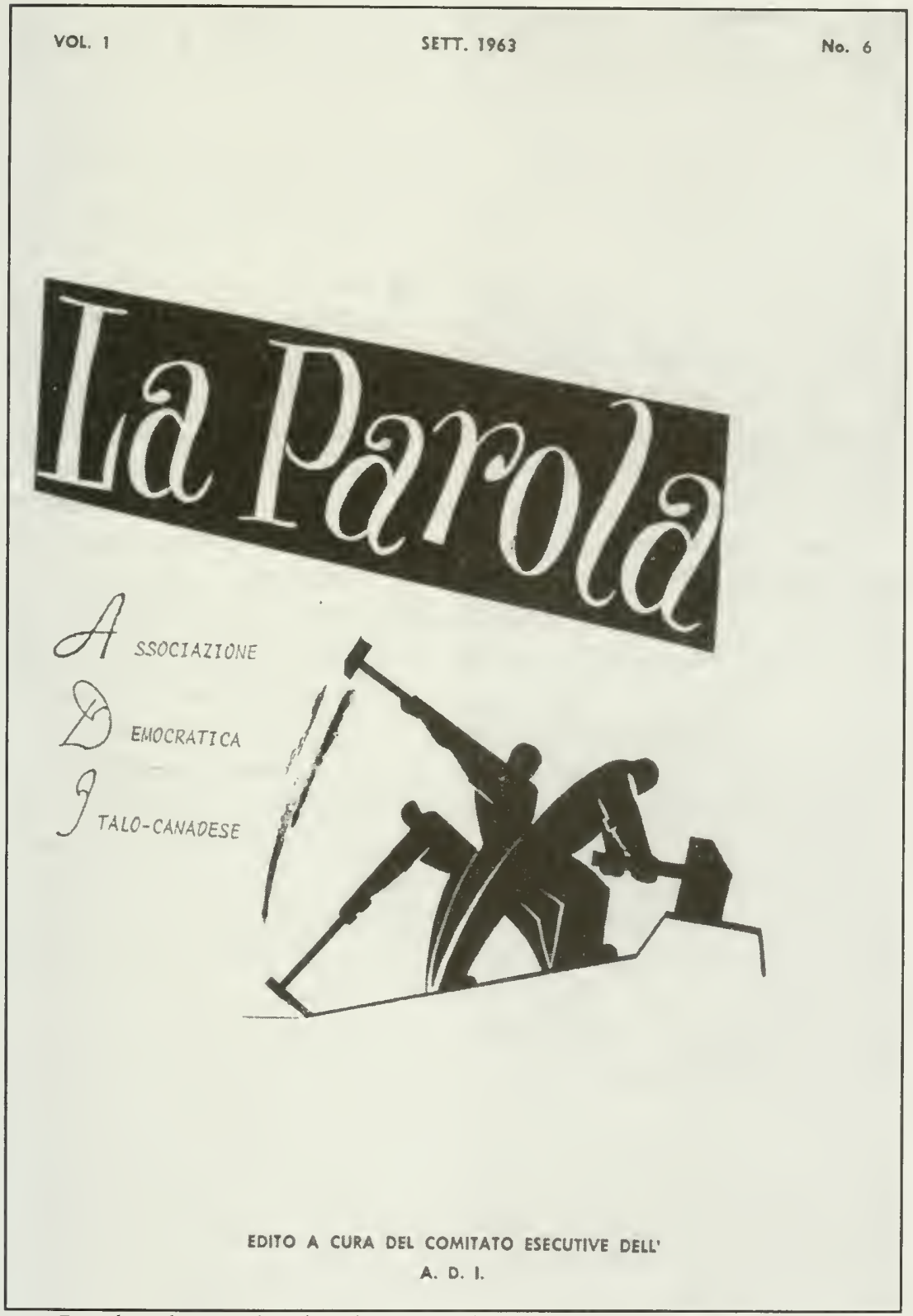

Besides the work-related issues plaguing the community, La parola tackled social and cultural matters as well. In the November 1963 issues, Giuseppe Mazzotta exposed the alienation of Italian immigrants who, wrapped up in their nostalgia for an Italy that never was, sought evasion in illusory pseudo-artistic activities. In an article titled "Chi siamo noi italiani che viviamo a Toronto?" (Who are we Italians living in Toronto?) Mazzotta 
explained the prevalent nostalgia as a form of alienation in these words: "One of the most important phenomena that we have noted in the last few years is the large number of Italians, women and men, young and old, who pose as writers 'in pectore,' poets 'in pectore,' singers 'in pectore,' and soccer players "in pectore," He then examines a song, "Emigrato abbandonato " (abandoned emigrant) by Luciano Salvatore and a film Accadde in Canada (It happened in Canada), possibly the first film ever produced and directed by an Italian Canadian, Luigi Petrucci.

With respect to the song, Mazzotta noted, "besides the obvious and consistent grammatical mistakes, the verses express the author's nostalgia for Italy. In a rudimentary manner, Italy is identified with the obvious image of 'oh sole mio' and Canada with the image of 'cold." Then he continued, "In its highest lyrical point, the poet expresses the hope that the metaphorical cold, which is both sentimental and moral, will one day end." In reviewing the film, Mazzotta gave the reader an idea of both the story and of its low artistic level: "Petrucci was able to create a sense of expectation in the society at large that, in matters of creative activities, is 'terra desolata' (waste land). [...] Though the film presents situations from everyday life-the death on the job of an Italian worker and the pathetic mishaps of a lonely girl-the film did not touch the core problem: the rhythm of life in an opulent society replete with contradictions, egoisms, tensions." Mazzotta concluded his review with the following statement, "What might have been the archetypical story of conflicting cultures (the relation between Canadians and Italians, [...]) was in fact [...] monotonous: as if the characters were all anemic. Further, the film is marked by an exaggerated opening and closing of doors and publicity for 0'Keefe [Brewers]."19

Another important issue tackled by La parola was the scandalous display of the Italian monarchist flag during official national celebrations of the Italian Republic. In 1963, during the 4th of November Victory Day commemoration of the Great War, the Italian monarchist flag was displayed at the entrance of the church of St. Mary of the Angels in Toronto. There, attended by the Italian ambassador and the local consul, a mass was celebrated to commemorate the fallen soldiers. A photograph of the incriminating flag was taken and published in the November issue of $L a$ parola. Under the photograph, the caption reads, "even this year, as in the preceding years, the Italian flag with the Sabauda cross was displayed at the entrance of the church of St. Mary of the Angels where a mass, attended

${ }^{19}$ La parola 1.7 (Nov. 1963): 10. 
by the representatives of the Republic of Italy, the Ambassador and the Consul, was celebrated. That flag offended the martyrs and the plebiscite of 2 June 1946." 20 The flag has never again reappeared.

In the precarious conditions of those pioneer days, the editorial group disintegrated and La parola, after just more than a year, ceased publication. The men and women involved in it were called to other urgent and personal necessities: employment, studies, and change of residence. The ADI, however, continued its organizational work and activities with the injured workers and the unemployed; it even presented a brief to the federal Commission on Bilingualism.

Between the demise of La parola and the birth of Forze nuove, another publication involved a group of young Italian Canadians: it was the weekly La carota. The first issue, a semi goliardic editorial initiative, appeared on 4 January 1969.21 It was a very modest publication, six partly typewritten and partly handwritten letter-size pages copied with a rudimentary duplicating machine and stapled together. Some issues, however, were much larger: n. 37 (24 November 1969), for example, was twenty pages thick. Its sarcastic name La carota, its untidy appearance, and its colloquial language constituted a strong political statement that suited well both the largely disoriented Italian immigrant community and the charged atmosphere of student unrest at the time. They also served to highlight the social problems within the community and the increasing world tension between East and West.

Published by the Italian section of the country-wide Company of Young Canadians (CYC), La carota was edited by a group of young women and men, who frequented the CYC Community Centre, located at 1725 Dufferin Street, just North of St. Clair Avenue, including: Antonio Amico, Roberto Bandiera, Maria Grifone (Italian Women Organization), Rick Slye, Bets Slye, Mario Micucci (a teacher), Leopoldo Bertacchi, (Steel

\section{${ }^{20}$ La parola 1.7 (Nov. 1963): 9.}

${ }^{21}$ Roberto Bandiera, one of the most active members of the CYC Italian group, emailed the following message to me: "Ho letto con interesse il tuo giudizio sulla Carota e mi rendo conto che hai azzeccato in pieno per quanto riguarda lo spirito che teneva uniti quei giovani che, fra le tante cose, pubblicarono anche $\mathrm{La}$ carota. Voglio precisare che il primissimo numero anziché La Carota, fu chiamato Comunità viva ed uscì verso la fine di Ottobre del 1968 quando ancora eravamo (CYC) su Edwin [Street]. A fine Novembre del '68 ci spostammo su Dufferin ed entrò a far parte del gruppo anche Domenico Pagnini. Si decise di cambiare nome. Io suggerivo "Il Pungolo" e Domenico La carota. A me stava bene anche La carota per cui andammo avanti con quel nome [...]." 


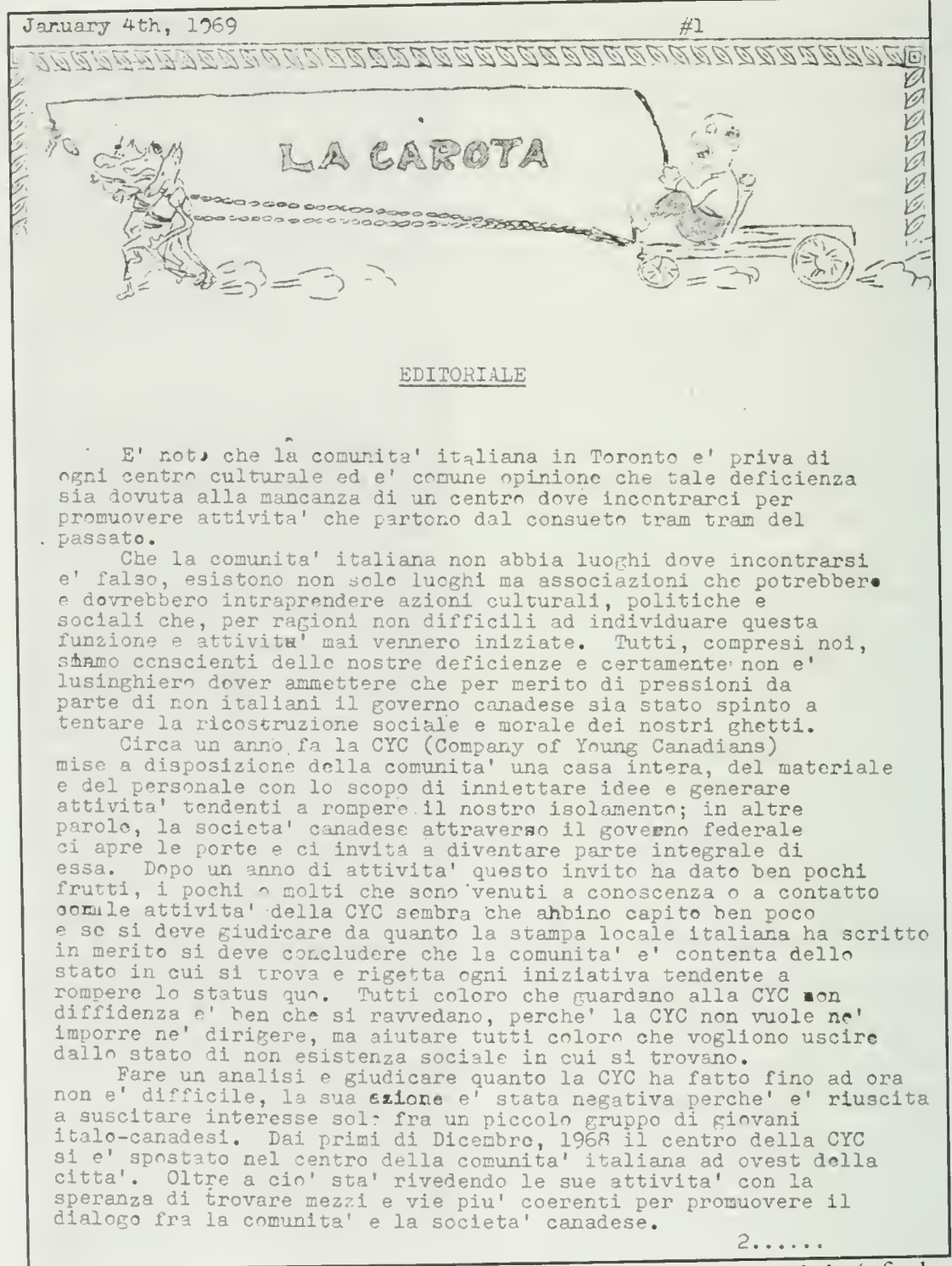

Worker organizer), Olino Capocchione, Domenico Pagnini (of the I.W.W.U.), Vince Gentile (of the A.M.C. \& B. W.), Joe Trito, and others. What held these young people together was not a common ideology but their youthful anti-conformist and iconoclastic views of the community.

La carota's first editorial was an indictment of those Italian Canadians who did not respond to the many appeals launched throughout 1968 by the CYC to get them involved in bettering the community and society at large. "After a long year of activities," the editors charged, 
our appeals have borne little fruit. The people who heard about us or came in contact with the activities of the CYC have understood very little of our objectives. If we have to judge from what the local Italian press wrote about us, we ought to conclude that the community is content and it is against any initiative aimed at changing the status quo. All those people who mistrust the CYC should review their positions: the CYC does not want to impose or to lead, but only to help those who want to change the condition of their social passivity. [...] having essentially social objectives, the CYC aims at making every Italian Canadian who works, pays taxes, lives and dies in Canada understand that until he/she refuses to accept this reality he/she is a dead weight on those who struggle to create a more human society in Canada. ${ }^{22}$

From the barely legible pages of La carota, its outspoken editors censured the self-proclaimed leaders of the community. They supported with keen interest the union movement, explaining the difference between Syndicalism and Unionism or Italian and Canadian ways of organizing workers. For instance, a series of three unsigned articles on the Italians' involvement in the union movement give an interesting synthesis of the two epochal strikes conducted by the Brandon Union Group in 1960 and 1961.23 The actual writer, Domenico Pagnini, described the two strikes as "belle e buone insurrezioni" (veritable insurrections), a definition partially shared by an important union leader like John Stefanini. ${ }^{24}$ To stimulate the Italian community's interest in local and national problems, the activist editors of La carota organized debates and wrote articles on matters such as education, Workmen's Compensation, women and work, immigration, Mafia, integration and related topics. Further, Stanley Ryerson, a Marxist historian, gave a series of talks on Canadian history to the members of the group and to the public in general. There was a film club, and some of the activists on one occasion staged a light comedy.

Though critical of the self proclaimed leaders of the Italian community, La carota defended John Lombardi when Tony O'Donohue accused Lombardi, and by implication the Italian community, of conducting Mafia-style deals. Lombardi had decided to run in Ward 3 as a candidate for the position of councilor in the 1969 municipal election. Later, changing his mind, he switched from Ward 3 to Ward 4 where O'Donohue was

\section{${ }^{22}$ La carota 1 (4 Jan. 1969): 1.}

${ }^{23}$ La carota 1-3 (4, 11 \& 18 Jan. 1969): 3-4, 3-4. Issue No. 3 is lacking in my collection (which, as far as I know, is the only extant collection of this weekly).

${ }^{24}$ John Stefanini defined the two strikes as "a peaceful revolution" in Bagnell, Canadese, 156. 
a candidate. In this connection, La carota wrote:

We are the first to criticize our [Italian] candidates when we feel that they are unworthy of representing our community and the citizens in general. But, above all, now, we violently criticize a serious slander brought against our entire community. Commenting on John Lombardi's decision to switch wards, Tony O'Donohue said, this is a 'dirty affair', adding 'it recalls the days when, in the American cities, gangsters used to meet behind closed doors and divide the city as if it were a cake.' Tony O'Donohue's imbecile slander comments on itself: it is an imbecile's slander! 25

La carota did not have a specific ideological orientation, but its iconoclastic attitude, youthful vivacity, and quasi-anarchist stand made its pages a singular reading in the left-wing Italian press in Canada. Following the demise of La carota, two other editorial enterprises on the democratic left ensued: Forze nuove (1972-1982) and Avanti! Canada (1975-76).

Forze nuove began as an election bulletin during the 1972 Federal Election in support of my campaign as the NDP candidate for the Davenport riding. After the election a group of members of the ADI "undertook to donate a small amount of money on a regular monthly basis in order to continue the publication of the paper." They were: Nivo Angelone, Elio Costa, Odoardo Di Santo, Tony Marcantonio, Matteo Matteotti, Domenico Leone, Angelo Delfino, Vince Gentile, myself, and others. After six issues, the monthly paper, a sixteen-page tabloid, was financially sound. The editorial board consisted of Elio Costa, Odoardo Di Santo, Tony Marcantonio and myself, remained relatively unchanged for the entire life of the paper, although other people joined for one, two, or more years and then left. 26 At first the editorial coordinator was Odoardo di Santo; then, for one year (1975-76), Franco Conte; and from 1976 on myself. Domenico Leone, Nivo Angelone, and Franco Lento, each in different

${ }^{25}$ La carota 37, (24 Nov. 1969): 15.

${ }^{26}$ Some of these passing members were Maria Augimeri, Gerardo Cimillo, Amedeo Corridone, Angelo Delfino, Mario Esposito, Franca De Angelis, Celestino De Iuliis, Vince Gentile, Tony Grande, Francesco Guardiani, Tony Lupusella, Teresa Manduca, Tony Marcantonio, Domenico Pagnini. I apologize to those whose names I have forgotten. Luciana Marchionne and John Picchione collaborated on specific cultural problems. Provincial and Federal NDP Candidates, members of Parliament, and members of the Provincial Legislature contributed with articles, news, and communications throughout the life of the paper. 

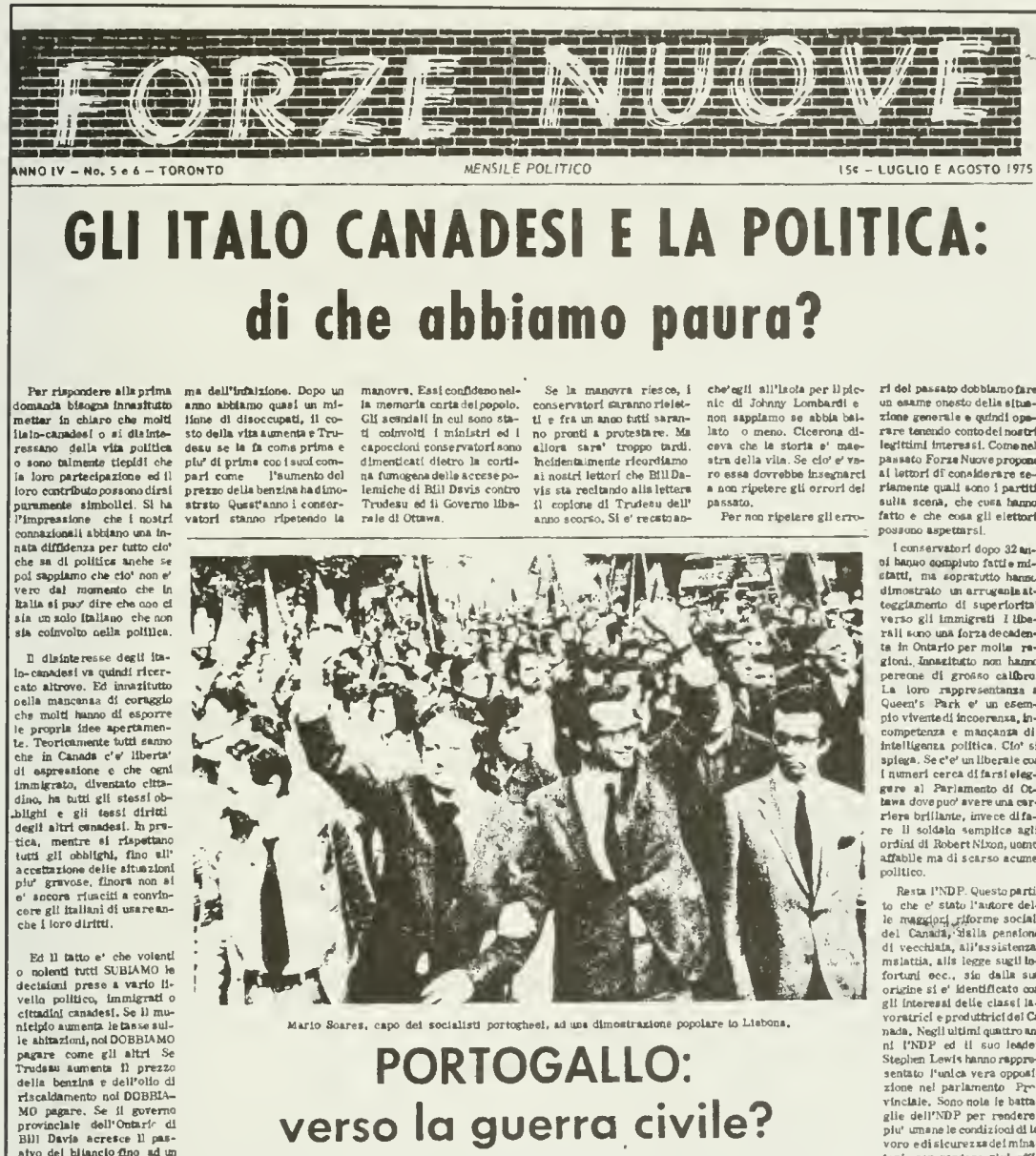

dol pascato dabblarvo tare zane zenerale o sudindl opelesitriml trreressi. Come nel

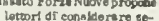
the che chesa gil elettrort

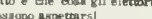
I conservatorl dopo 32 ans-

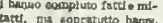
ilmostrato un arrusenle atverso gll immigret $I$ tuberall ino una forza decedengioni. Innecitucto not hamo pereche of grosso callaro. Quera's Park o' un esemplo vivented dincoerenua, byincolliganzas politica. Ciso" si apless. Se c'e' un llberale con gero a) Parlamento di $a$. Hera brillantle, invece difare II soldalo sumplice agli ordinid al Rabert Niloos, uomo Resta I'NDP. Questo parti-

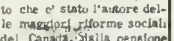
1 vecthata, sijtessistenza malattia, alls legge sugll toorvisine si e' iventilcato can

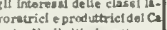
pada. Nesll litimi quation onit l'NBP ed II suo lesplor Steolien Lowis hanno rapproxlone nel parlanento $\mathrm{P}_{\mathrm{r}}$ vinclaie. Sono nole le batta-
glie dell'NDP per rendere

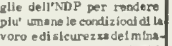

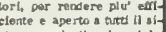

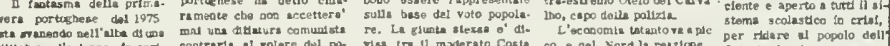

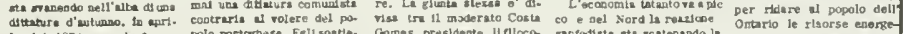

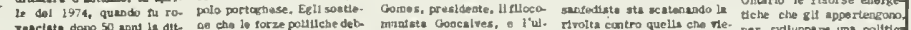

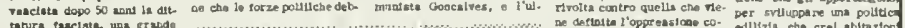
tatura fascelstich una gratide

partachani.

Era clunte auche por esal venne poro" mobto la cluats gnturare con the sue subs. rue ed lestrealats delt. ro th slostiud per is cantl. twots che dethero al pertito roll - solo 1113 per ceoto

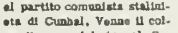
Do al meso sel giarable Repubblice, l'valeo ta mano comusitat

Ora la sthazboas sta pre-

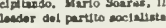

\section{SOMMARIO:}

La tassa sulle case Pagina 4

Le elezioni provinciali Pagina 6

Gli immigrati e la scuola Pagina 8

L'alternativa N.D.P. Pagina 9

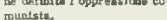

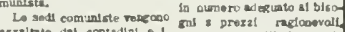

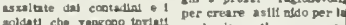
4 aedere le rivolta, tilore inso

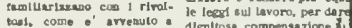

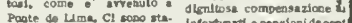

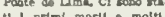
Intortunard e penulanidecont

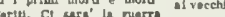

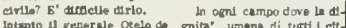

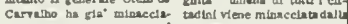

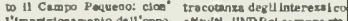

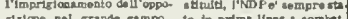

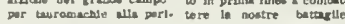
torta di lutione

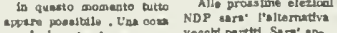

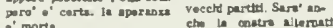

periods, took care of distribution, advertising and promotion. In a synthesis of the role played by Forze nuove in the community, Odoardo Di Santo wrote, "the newspaper took on a dual nature. First, to fight the establish- 
ment within the Italo-Canadian community, and secondly, to debate the broader political issues as they affected the Italo-Canadian worker." 27

In the present essay, it is impossible to analyse in detail eleven years of editorial activity and political orientation, which branched out in several directions: local, provincial, national, Italian and Canadian, and international, as well. It may be said, however, that Forze nuove's basic editorial policy was critical support for the NDP and the union movement. Regarding the NDP, the paper always pressured the party to recognize publicly the immigrants' important role in the economy of the province and within the party. To make this point clear, key articles were published in Italian as well as in English. Prominent personalities of the NDP, such as David Lewis, Jan Dukszta, and Melville (Mel) Watkins of the Waffle group, a radical current within the NDP, enlightened with their writings specific aspects of the Party's national or provincial policy. This helped gain allies among the ethnic groups within the party and among the Wafflers, who in the late 1960s and early '70s were a very active group. Along with the Wafflers, ADI and the editors of Forze nuove all shared a radical approach to workers' issues. The ADI membership, however, could not share the Wafflers' strong and enthusiastic nationalism, which to Italian ears sounded like another form of fascism.

As mentioned, Forze nuove and most of the people behind it kept a critical affiliation with the NDP. More than once ADI stood against the Provincial Executive in matters of policy or when it tried to parachute candidates in ridings where the Italian vote was strong and ADI had a wide base. For example, the NDP executive and ADI confronted each other during the nomination in the Dovercourt riding for the 1971 provincial election. The nomination went to Steve Penner, who had the support of the $\mathrm{ADI}$ and the local Italians. ${ }^{28} \mathrm{~A}$ similar confrontation occurred in Downsview for the nomination of the NDP candidate in 1975.29 Perhaps the desire to have a more docile Italian group induced the Provincial NDP exec-

27 Polyphony. 4,1 (1982): 123.

${ }^{28} \mathrm{See}$, "L'ADI è l'unica associazione politica socialista italiana," by Egidio Marchese in $1 /$ giomale di Toronto (31 Aug. 1971): 5. In the Dovercourt riding, the P'rovincial executive opposed the candidacy of Steve Penner. Penner almost won the seat. He was declared the winner on election night, but after a recount it was determined that he lost by only 39 votes to the PC candidate George Nixon. After the recount the final results were: George Nixon (PC) 6,183 votes; Steve Penner (NDP), 6, 144; Dan De Monte (Lib.) 5,116; and William Steward (Com.) 429.

${ }^{29}$ See Forze miove (Sept. \& Oct. 1975): 7. 
utive to go along, after some initial resistance, with the creation of the shortlived NDP Sezione Italiana (Italian section) and the publication of Avanti! Canada in 1975-76.30 Both initiatives were fully financed by the Party. Several young idealists, men and women, staffed the Sezione with enthusiasm, among them: Mario Ciccoritti, Nino D’Aprile, Ugo Pennaccino, Nivo Angelone, Mauro Buccheri, Peppe Cutellé, Fernando Di Marco, Caterina Mele, Silvana De Bona, Cosimo (Mino) Stefani, and others.

On more than one occasion the ADI and the Sezione found each other on opposite sides. For example, in the 1975 Downsview nomination, ADI and Forze nuove endorsed Odoardo Di Santo while many members of the Sezione supported Allen Shapiro, the candidate favoured by the provincial Executive. Once nominations were over, however, both Forze nuove and Avanti! Canada supported all the NDP candidates during the election; and the people involved in both newspapers worked hard in the campaigns to elect the Italian Canadian candidates: Odoardo Di Santo in Downsview, Tony Lupusella in Dovercourt, Tony Grande in Oakwood, and Ross McClellan in Christie.

Within the community, Forze nuove regularly brought to the forefront issues relevant to workers in general and Italian immigrants in particular. Some were old questions relating to the construction industry: safety on the job and the reform of the Workmen's Compensation Board. Other matters involved second generation Italians, the problem of teaching Italian in the public schools, and the abolition of "vocational schools." These schools essentially had the unspoken objective of channelling children of immigrants into manual jobs, often regardless of their ability or their parents' wishes.

Regarding the teaching of Italian, Forze move maintained that it was the provincial government's responsibility to ensure that Canadian-born children of Italian parents (or other ethnic groups) received the education they deserved, including the teaching of Italian (or other ethnic language) if demand warranted it. When, in the summer of 1975, the Italian government decided to provide funds and coordinate personnel for the teaching of Italian in Canada, Forze nuove stood firm against such a move, considering it an intrusion that actually exempted the provincial government of its own responsibility.

${ }^{30}$ According to Mario Ciccoritti, whose idea it was to have a Sezione Italiana of the NDP, the Provincial Executive of the Party initially opposed the idea. "It was a member of the Executive, Gordon Vichert, who insisted, pleading our case convincingly," said Ciccoritti. 
The Italian government's initiative was contrary to the objectives of Italian cultural associations on site, such as the Dante Society, which were pressuring the provincial government to assume its responsibility regarding the education of the children of immigrants. An article signed by E. C. (Elio Costa), but discussed by the entire edirorial board, clearly stated Forze nuove's position on this issue. "It is pleasing to see," wrote Costa, "that after much lobbying, the Italian Government has increased funds and has sent personnel to help promote the Italian language. However, the objective of the personnel sent from Italy should have been to help the local Associations, not to take their place." He then goes on to state that, "the struggle (that the various local cultural Associations have undertaken to obtain from Canadian authorities the recognition of the right of language instruction) is undermined. All the activities of local associations were directed to obtain from the Provincial government the commitment and, consequently, financial and organizational responsibility to educate neo-Canadian children in the language and culture of their parents." 31

Though interested in international problems and in the political life of Italy, the main interest of Forze nuove was Canada and Italian Canadians. It did not shy away from biting criticism of the Italian community leaders when these leaders' uncommitted position avoided dealing with real problems facing workers and the community. Moreover, although the articles were often too long, they were written in plain and direct language, adapting in style and content to the need of the average Italian Canadian reader who, generally, had a grade five education or less.

The political position of Forze nuove and Avanti! Canada was similar, though the two papers differed profoundly in how each viewed the relation that Italian Canadians should have with Italy. Avanti! Canada welcomed to Canada the activities of the Italian political parties while Forze nuove opposed it. For example, in a piece published in its first issue, Avanti! Canada, in a polemic with the Federazione delle Associazioni e Clubs Italiani (FACI) and indirectly with Forze nuove, argued in favour of the Italian parties' involvement in the community. It maintained that the assistance provided by the "Patronati" would help integration and enhance Italian workers' interest in Canadian politics.32 "We must say," wrote

\footnotetext{
${ }^{31}$ See Forze nuove, September \& October 1975, p. 7.

32 Patronati are agencies created by major Italian political parties to provide much needed assistance to emigrants who have to deal with Italian bureaucracy both in Italy and abroad. The Italian government finances them in proportion to the number of people they assist.
} 
Avanti! Canada, "that the Italian Government and the Patronati's interest in the conditions of Italian emigrants' lives in Canada neither prevents nor slows down the process of integration of our fellow countrymen in Canadian society, but aims to enhance and accelerate it." 33

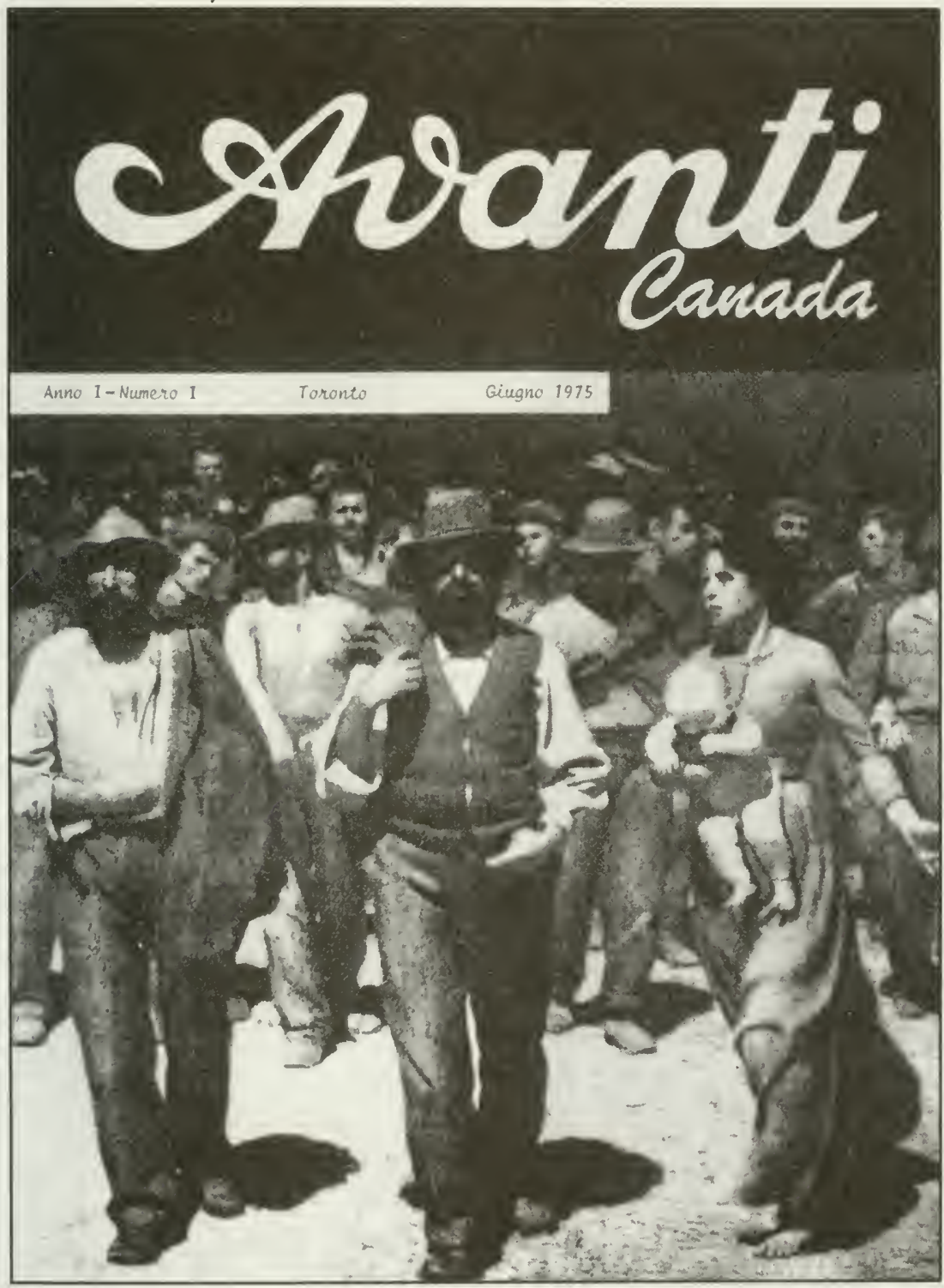

33 Avanti! Canada 1,2 (1975): 4. The editorial board approved all articles before publication. Articles from persons who were not part of the editorial board bore the signature of the respecrive authors. 
After just over a year of activity of the Italian Sezione, which involved dozens of Italian youth and many militant men and women, the NDP provincial executive decided to cut the funds that paid the rent for the St. Clair Avenue office and the secretary's salary. The Sezione thus came to an end and with it so did Avanti! Canada. Soon after it ceased publication, two other left-wing newspapers sprang up in Toronto in 1977: Lotta unitaria (United struggle) and Nuovo mondo. The former was the organ of the

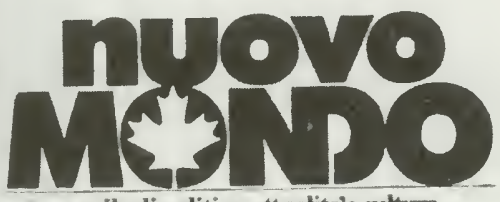

mensile di politica, attualita'e cultura

ANNO III N. 7 LUGLIO 1979 - 25 CENTS.
La crisi energetica negli USA

Le sette sorelle contro Carter a pag 8

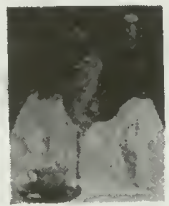

La poesie

di Mary Di Michele a pea.7

Per la prima volta un socialista potrebbe diventare capo del governc

\section{INCARICO A CRAXI}
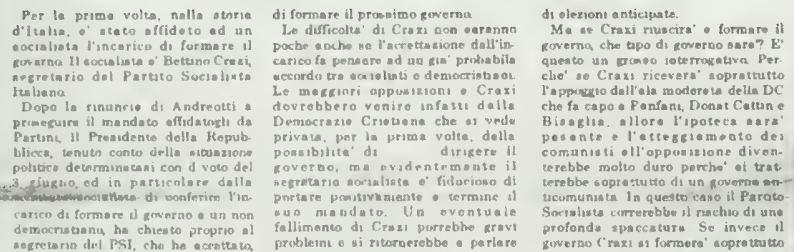

\section{La visita in Canada di Dino Pelliccia}
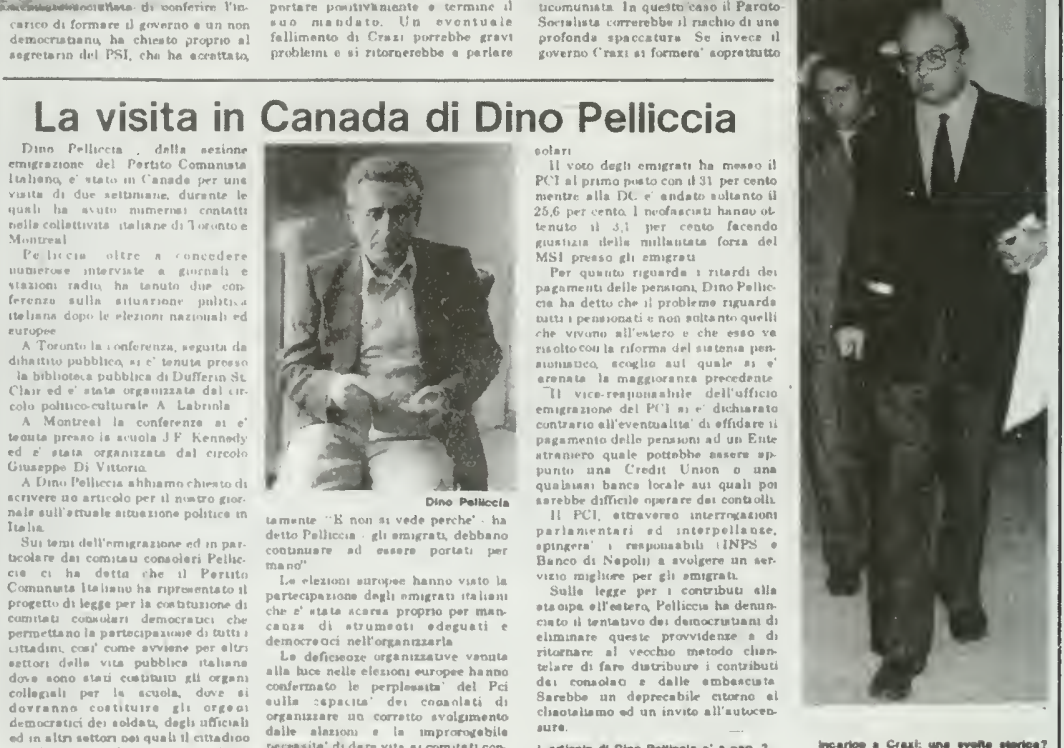

per portare al governo lo claene avora crive in wao apirito unitatio ed in funkioge interlocutoris. per far delle siantra, come contsoa Sianonle, allora il disconso e' divemo uncker ae va

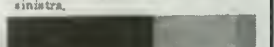


Italian Club of the Canadian Communist Party (CCP) while the later was financed by the Federazione Italiana Lavoratori e Famiglie (FILEF), an emanation of the Italian Communist Party (PCI). These two publications were the result of inner conflict between those at Nuovo mondo who supported Euro-communism and the PCI's break from the Soviet domination; and the staff at Lotta unitaria who supported links with the Russian Communist Party.

Lotta unitaria expounded unimaginatively the policy of the local Communist Party with long monotonous articles. Ignoring the elementary rule of journalism, there was, it seems, no desire to make the paper attractive and appealing. ${ }^{34}$ The first issue, six tabloid pages in length, featured five articles. These included a two-page editorial and another four pieces that discussed "Wages and Profits," "April 25" [Italian Liberation Day], "Racism," and "The Quebec Problem." Some improvement in appearance occurred in successive issues. In general, however, it was a paper by the faithful for the faithful, with no impact on the community.

Nuovo mondo was more dynamic in style and language. In the Canadian political scene it supported the NDP and ignored the hard-line CCP. This was the new direction taken by the FILEF, following the Italian Communist Party's reformist policy for Euro-communism. Explaining the paper's policy, its editor Franco Conte wrote: "Nuovo mondo maintains a critical approach on workers' organizations; for example, towards the New Democratic Party and Canadian unions." 35 But when Nuovo mondo shifted its attention from Canada to Italy, its political views changed as well. In Italy, the attention focussed on the Communist Party, and the socialists were also occasionally discussed. The communists' political initiatives in favour of emigrants on both sides of the ocean were continuously brought to the attention of the readers. ${ }^{36}$

Nuovo mondo had a circulation throughout the country that was greater than that of any other left-wing newspaper. Having being estab-

34"In a newspaper the material [news] is nothing without packaging; the text is nothing without the context," wrote the renowned French intellectual René Uncheau, as quoted by Paolo Murialdi, Come si legge un giornale, 14.

${ }^{35}$ Conte, "Nuovo mondo,"Poliphony 4.1 (1982): 126.

${ }^{36}$ The following is one of the many possible examples: the article "L'emigrato nelle liste del PCI" reads in part: "The PCI's interest in the emigrant workers and their problems is not revealed solely during the XVth Congress, nor in the resolutions approved for the program of the European election; a new proof of this interest is the list of candidates for the next election of 3 and 10 June, and in the electoral program approved by the Central Committee recently held." Nuovo mondo (May 1979): 10. 


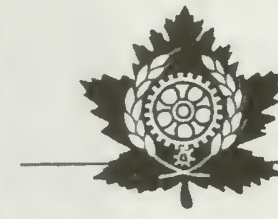

ONTARIO: PERCHE' VOTARE PER IL PARTITO COMUNISTA?

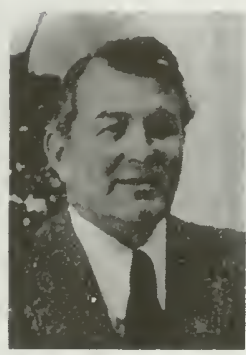

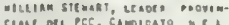

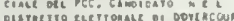

Con alcunt elornt risaati in queath caspacana COMTA TIIT TARI opportuno 10 forane 1 suo lottort sullo poarziont dol Parrito cominiot alcunt punti salient1 10 queat' olezione.

a tele 300, Lotta On1ta ria ha intorvistato il losder Provincialo por I Ontario, Willias stowart cho coscorre sol disetret to - lotteralo di DOVEPCOUPT dolla citta' di Toronto. L. V., Coapagno Stowart, data l'alta disoccupariono cho arfliego 11 Canada tutt1 gli altr1 pseal capl problesa della deoccupaprobien dalla debccupenes alo in quaet. elosione? Storart. Certemente, 11 problemargioro in que sta lezione oi lo crisi

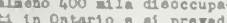
che aresto aumero aumest ben proto a aze nillon Queota o' une tragedia por catatinat o els

\section{WINNIPEG:}

NASCE NUOVA CELLULA ITALIANA DEL PCC

L' urdSCl Easg10 Bcorso - etato lotto a 1 con1pos vo della, 11 priso dirot ANTOHO ORUSCI OOS1' Manl coste roalizzando 1. expi-

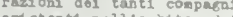
quelis coaunien' I tallana. La fordarsone di un'altr. collula in liagua 1 tallaso del Partito Coauniate Cang pod tiro: angoiozente di famiglie de lavoratorl. opecialsoote gl1 1 malgrati che hanno seno anzlant to will levoro, a is particole re le doune 1 gávent. a notato cto anche 19 Ongorans $\mathrm{cos}$ tanto di ieurs - di apeciallzzazions, oon reore lavoro. Quegto ' mevz'altro 1] probitua anclore an 11 governo dell'Ootarlo nos L'unica sua solvzione: i. dare plu' concessiont Hecall o increastare Mile erandi corporazioni. ceap10, quearo soverno ridotto di 36 ellions di vano pazaro lo grandi corporaziond, aectre ba aumeg

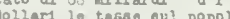
lavoratore.

I1. Boverno di Davis disce che queate thisure avrobber ereato plu post a lavora Ma la do poceupazi oso 1oveco - aumeatata drameticaneato 6000 dimioulti 1 soldy A Lache 11 coatrollo dollo paghe,cho 11 Eovarno provid Figore, In Ilduzione de aervizi soctall banno costribur to alla droccupazioco. Sol taato 10 corporatat on bano decorrciaco da queato lit ant1-popolari. dello partito comanterto ba problea della dteocenpar probli an della dreoccupazio pone is costruzistana gra 200, $>0 \mathrm{C}$ case all'ane 1 proesize ero and dagl1 speculatorill costo dollo bitaz1001 devo to d1 35,000 ad un aans 835,000 dollart \& ug"aortage"di aon piu" dol

adice del 20 st1? Uppo 1 deo lact co-poIt ticonopiale des larorstor. 1a perticolare dolliatosaíl caza ono dollo 11 ootogno el partito del Lavoratorl, 11 Partito Cosuni ta, Inoltre un parso arant1 por la cauca ano us Canads 11 cocialscosparni.

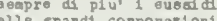
dollart is tasao che deve Tart1 augur1 al auovi

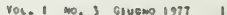

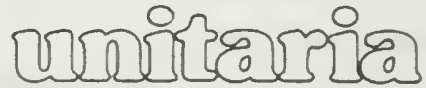

IEISTA CANADESE

6\%. vaeto metterobbe a Lavorare 1 diseocupat1 sel 1. alire lodustrie a creaplu posti d lavoro. isoltre 11 govarao deve nazlonallzzare lo noatro Fleore haturali, orilupp ro I'industris a anufot turero eecosdaria.... Non ba ena lasciare lo decielona coscersearl 11 Nituro del. sostss proviscla, del aostionante

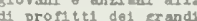
nonovols.

U., Qual'e' ia poscion Partito Comunts: aulle adute o sulza alcurezas del lavoro?

Stewart, Lm matcior parte de1 10vorator trascorrono

\section{BASTA CON L'AIB!}

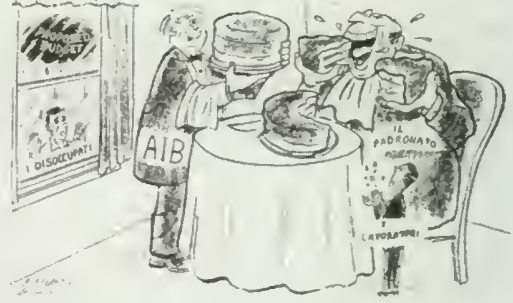

Continusino ad euseratare conars ds plu' 1 prezzi. prorsti, le tasso, $12 \mathrm{cg}$ oto doll'enercla, $11 \mathrm{rit}$ cepl di abbigl

Oltro al Berrizi socials todiepongabll1 od ogna lareratore, soco otsti tack ati fondi Pranziasent1 Razitona a solo diacap1 to de1 onarl 1s pollttea dol faternes det prort tot del 20 Brand comparte aul t1aziogall, otota la caue della perdits d levoro per bislla1e di ieverat.

11 popolo lavoratore? 1. clase aparas dovono acuotersi dello spalle 1 attiaceo seapra plut cont1 aul troaziopals del monope 11 - dol goterno ohe atanno attaccendo 10 teaso tenore di rita degli oporas. lavorator

NoD c1 coso valldo reglo ni per abbasbaro seapro di piut 1 ealart roals do oul poato di lavoro e quepta dorrebbe eosere u० culturale dolle 20 ro estInvoce lo condizio at davoro sodo dreotat atollorarill a cakas doll alcoso del rilaso di lavora alla logorszone, 18

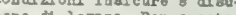
1) Candaro. Per queato 11 Canada ba la mageriors 1) Canortuale di locidenti di triste priasto canadoso. II govordo ata st tribuen qualt papo 1 lavozetor 1 nop "tare atteantose" aul voro. Ma la rara golnzio al problema of di tar d) cho 1 lavorator 1 . conto mus . ...s. B...stimer pesopo portare avant1 une 198a cela moball taziono di masse per uns oztone politica s por far proselone Gono: 11 movisento alsdaca 11 Partito Comuniota.

Solo ua azidao cosgruat rondarantel sella lines politica del pasas.

Tute1 gll operal, tutti 1avorators 1 progrenel ot1; davoso lottaro per risuovero 11 coatrollo del aslart, dovoso chiedoro $1 \mathrm{~s}$ contion de auov poat1 Do do diritto alla coatra tesiono collettiro.

Che ell avmenti de12。 pagto elochiso un ieporten del creare $10 \pi=$ zlog ' una rizlose senzo

Qualcosa devo oosere firto oubito per settere 2122 to dello rurto legaclasse operal a d a - i lortarto occidenta dis queato forzo pud porta popolo lavoratore.

lished by the FILEF, which had branches in several Canadian cities in Eastern as well as in Western Canada, the paper had offices in Montreal, Toronto, Winnipeg, and Vancouver. Mail and articles from these and other Canadian cities were continuously received and published and the paper was sent in bundles to these offices, which looked after its distribution. 
The impact of these left-wing publications on the Italian community was generally positive: Forze nuove lasted eleven years, the other periodicals much less and circulated mainly among the radical groups in the communities in Toronto and Montreal. As far as Forze nuove is concerned, an average of two thousand copies per issue were printed, of which over 600 copies were sent directly to subscribers mostly in Toronto and the rest were distributed through Italian outlets in the city. Its readers were mostly workers, tradesmen, acculturated professional people, and white-collar workers who placed themselves politically on the democratic left and were NDP or Liberal party supporters. La parola and La carota were bulletins of the ADI and CYC respectively and circulated mostly within their respective membership. Avanti! Canada was created in preparation for the 1975 provincial election and most of the NDP ridings in Toronto had it as a brochure for their electoral campaign with the cover page carrying a photograph of the riding's candidate. Though widely distributed, Avanti! Canada did not have a lasting impact on the wider community. This was also the case for Lotta unitaria and Nuovo mondo. As a whole, however, all these publications, each in its own way, strengthened the interest in a more democratic and multicultural Canada.

\section{Right wing newspapers}

Turning to right-wing publications, the political landscape and the ideological perspective changes as well. The chief interest of the right-wing periodicals was in Italy and what was happening there. Some Canadian content found space in Il faro and Occidente, but only as a reflection of Italian politics or of the newspapers' anti-communist stand. The local neo-fascists' nationalism and their emphasis on "loyalty" to the white race, the nation (Italy), one man (Mussolini), and a party (Fascism), define the Italian rightwing militants in Canada as men and women in exile, even though they came to Canada willingly and of their own choice. It is also true that in Canada Italian neo-fascists did not find a Canadian party to dialogue with, as the socialists had with the NDP and the communists with the CCP. As a result, their isolation or exile was both ideological and factual.

Furthermore, because of their interest in Italy and her political problems, the neo-fascist publications marked the intestinal struggle that led the Movimento Sociale Italiano (MSI) from post fascism, to beyond fascism, and finally to the democratic conservative position of the Alleanza nazionale party (AN). As we will see, the four titles (Rivolta ideale, Tradizione, Il faro, and Occidente) articulated different ideological positions and the political discourses they exposed reflected those both inside and out- 
side of MSI. Rivolta ideale echoed the voice of the most intransigent and racist current espoused by many veterans of Mussolini's Italian Socialist Republic. Tradizione, on the other hand, affirmed its link with the Centro Studi Ordine Nuovo (ON), the youth extremist right-wing movement led by Giuseppe (Pino) Rauti, a follower of the reactionary philosopher Julius Evola. Il faro interpreted the hopes and perspectives of the MSI under its historical leader Giorgio Almirante in the early 1970s, and Occidente expounded the bourgeois conservative views that in time led the MSI beyond fascism to the founding of the Alleanza nazionale (AN).

The bimonthly Rivolta ideale appeared in Montreal in October 1964. Its title was taken from Giovanni Tonelli's weekly paper, La rivolta ideale, the first overtly fascist periodical to be published in Italy after World War II, which had first appeared on 11 April 1946. The Italian Canadian Rivolta ideale (written without the article ' $\mathrm{La}$ ') was the product of a collaboration between two very radical right-wing associations: Unità italica in Montreal and what later became Centro culturale tradizionalista, Italia d'Oltremare in Toronto. The promoters and leaders of these two associations were Vittorio De Cecco and B. Chittaro in Montreal and Stefano Sinicropi, Severino Martelluzzi and Domenico Capotorto in Toronto. The chosen birth date for the neo-fascist publication was October, the anniversary month of the fascist March on Rome that, on 28 October 1922, led Mussolini to power.

While Rivolta ideale was launched in Montreal to mark this historical date, Italia d'Oltremare in Toronto distributed a leaflet prepared in Italy by Ordine nuovo (ON) for Italian immigrants and sent to all its contacts abroad. The leaflet reads as follows:

\section{ORDINE NUOVO (Our honour is named loyalty)}

Italian youth abroad should remember that forty-two years ago, the world subversion had chosen Italy as a land of conquest.

The genius of our race (stirpe) rose and created the miracle of a heroic resurrection.

Today, through socialism and the democratic left, international communism launches its offensive, aimed at hoisting the red flag on the Campidoglio in contempt (dispregio) of our civilization.

Today, once again Italy has been chosen as a land of conquest.

In the name of the traditional values of our race, we ask for the solidarity of the Italian youth abroad to stop the advancing Bolsheviks' baying hordes (canea). HISTORY DOES NOT PARDON COWARDS. ${ }^{37}$

37 The leaflet was created by Ordine nuovo in Italy and sent for distribution abroad. It was their reaction to the Christian Democrats' opening up to the socialists and creating the first centre-left government in Italy. 


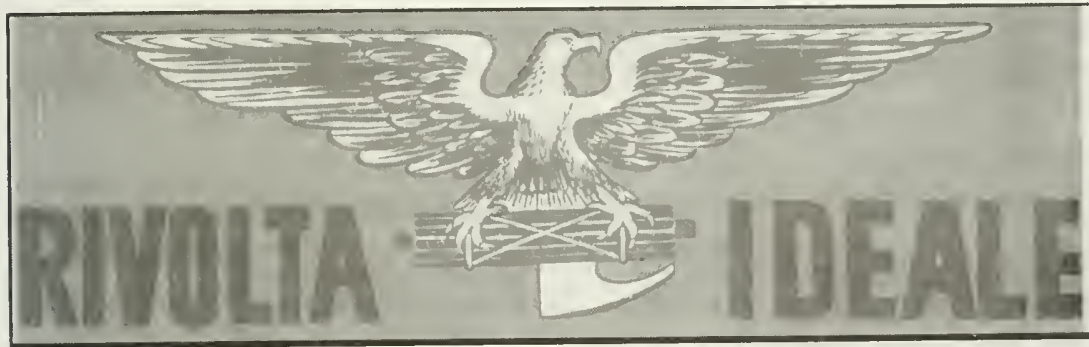

ARNO 1 - NUMERO 1 -

MOITTREA - OTMOBRE - NOVEDRE 1964

Esce ogni 2 mesi

GIORNALE OPERAIO ANTICOMUNISTA ITALIAHO

OEDICATO ALLA LOTTA CONTROIL. BOLSCEVISMO INTERNAZIONALE

E TUTTE QUELLE FORZE CHE VOGLIONO LA FINE DELLE RAZZE DELLE NAZIONI DEL CRISTIANESIMO

BATTE PER IL TRIONFO DEI PRINCIPI FONDAMENTALI DI GIUSTIZIA NAZIONALE DI STATO DI PATRIA

\title{
II PASSATO ED IL PRESENTE
}

\begin{abstract}
"Rivolta Ideale" evedele al passato etorico del Fagcismo e di quello che cl ha inetgato. Nol non rinneghiamo gli errori, wa ron neghiamo nemmeno quello che il Fascismo e Musgolini hanno fatto per l'Italia ed il suo prfolo. Oggi, dove wolti volta gabbani trovano comodo sputare sul piatto che leri wangiavano, e divenuto un delitto parlare del Fasciamo con ginceritr e con onesta. Sono circa 20 anni che comunisti e democratici sputano fuoco e fiamme sul Pascismo ed i suoi rappresentant1. Ad un giovane ignaro della storla recente d'Italia,e sopratetto del periodo che va dal 1922 al 1945 , puo sembrare che questi anni olano stati il periodo piu nero della gtoria Vezionale. Tut to questo si capisce facilmente ge si penga all' enorwe propagands anti- fascista fstta nel wondo dalla fine della guerra in poi. Noi giovani e meno giovani, che ci aiamo riuniti attorno alla flama lazionale con ung volonts suprema di rinnovamento morale, gociale, liazionale sappiamo che nonostante tutte le menzogne di osni giomo e di ogni colore, la realta storice. del Fascisuo resta e resterl nelle storia d'ltalie come un'esempio Iuminoso d1 Italianita, come uno sforzo oplendlan di guarire e cambiare radicalmente mali che sono fin troppo conosciuti e tipici della Niazione Italiana. Il Fagcigmo t ouell'idosle per cui molti Italiani hanno imparato a vivere dignitosamente e non da lustrascarpe al soldo di. stranieri e di idee straniere. Il Fascismo fo quello che realizzo ia bonifica delle peludi Pontine, che diede all'operaio la Carta del Iavoro, e le prime protezioni sociali in suo favore. Il Fascismo ha il merito enorme di aver voluto e stabilito 11 Cồdato con il Vaticano mettendo cosi fine ad una polemica storica che la Magooneris Italiara ed Internazionale alimentava nelle coscienze di ogni buon Cristianc.
\end{abstract}

Besides nostalgic commemoration, there were practical and immediate political reasons for the ultra-rightist militants' bold and alarming appeal to Italian youth abroad. The reasons are evident in the leaflet. The words "socialism and the democratic left" refer to the fact that in December 1963, the first centre-left government headed by Aldo Moro had taken office in Italy. Members of the left-wing Italian Socialist Party were part of the government team along with "the democratic left", the Social Democrat Party of Giuseppe Saragat and the Republican Party of Oronzo Reale. This pointed to a new direction within the major Italian political party, the centrist Democrazia cristiana. ${ }^{38}$ A centre-left government in

${ }^{38}$ Salvadori, La Sinistra nella storia italiana, 148. 
power dashed the MSI's hopes created by Arturo Michelini's policy, which had given the party its brief taste of success when, in Parliament, it held the deciding vote in the centre-right coalition headed by Fernando Tambroni in 1960.39

As the leaflet in question clearly indicates, ultra-rightist militants drew an analogy between the centre-left government of 1964 and the political situation in 1922: now as then, Italy was seen to be under attack by Bolsheviks or "international subversion." As will be detailed below, the leaflet linked Toronto's radical group, Italia d'Oltremare, with the anti-parliamentarian Italian right-wing youth movement that in 1956 had left in protest the neo-fascist MSI. That year, supported by democratic conservative and "tame fascists", Arturo Michelini had been reconfirmed at the helm of the MSI. He defeated Giorgio Almirante, the radical historical leader of the party, who had the support of three radical groups: the socialist oriented veterans of the RSI, the hard core fascists, and the youth movement. Michelini continued his moderate policy, aimed at fitting the MSI into the democratic system and within the parliamentary process, and met with some success. With the approval of Enzo Erra, the youth representative on the Party's national executive, Michelini decided to limit the autonomy of the youth movement. This strategy was necessary because some

${ }^{39}$ Several political and economic factors led to the failure of Tambroni's centerright government, but the event that revealed all the opposing components was the violence that followed the MSI's decision to hold its Congress in Genoa-a city awarded a gold medal for its armed resistance to fascism. All anti-fascist parties, unions, associations, and individuals considered that decision an insult and a challenge and all rose in protest and organized demonstrations throughout the country. In the truculent authoritarian political mentality of the day, police crushed the demonstrations, killing several men in different parts of the country. In Toronto, Corriere illustrato (16 July 1960) titled its editorial "Undici morti, mille feriti: responsabilità comuinista" (Eleven deaths, one-thousand wounded: the fault of the communists). As a consequence of the brutal methods employed by the "celerini " (motorized police), Tambroni resigned and with him ended the centre-right experiment in Italy till 1994. Years later, spokesmen of the MSI, such as Domenico Minnitti, recalling those events, stated: "It was a mistake to choose Genoa as a location for our Congress," see Nicola Rao, Neofascisti!, 82. In Canada, from its anti-communist perspective, Corriere illustrato (23 July 1960) found that "Tambroni ha reso un grande servizio alla vera democrazia." The following week (30 July 1960), an editorial in Corriere illustrato commenting on the violence and the eleven deaths cynically wrote, "I comunisti, andati per suonare sono stati suonati " (The Communists, who had gone to cudgel, have instead been cudgeled). 
uncontrollable elements of the movement undermined through acts of violence and bravado the democratic image that Michelini tried to bestow upon the party. Headed by Pino Rauti, a disciple of the philosopher Julius Evola, a large portion of the youth movement left the MSI and created the autonomous radical Centro Studi Ordine Nuovo.

The schism between the youth movement and the MSI was generational, ideological, cultural, and political. Under Michelini, the MSI was on its way to becoming another of the many Italian parties in line with the Western world against communism. While accepting Evola's anti-modernity views, the youth movement was, however, opposed to both Western capitalism and Russian communism. For, as Evola stated, "Russia and America appear as two different expressions of the same thing, as two ways leading to the formation of that human type that is the ultimate conclusion of the processes that preside over the development of the modern world." 40 For Evola's followers such as Pino Rauti, both systems were the product of the same phenomenon, modernity, and had do be uncompromisingly opposed: according to Rauti, Evola led the young right-wing radicals away from their parochial fascist culture to a worldwide horizon of an international kindred of men and ideas. "Evola profoundly changed our convictions and provoked a cultural revolution in our world," Rauti recalls. 41

${ }^{40}$ Evola, Revolt Against the Modern World, 344.

${ }^{41}$ Pino Rauti, quoted by Rao, Neofascisti!, 41. A man of many talents, Baron Julius Evola like the French René Guénon advocated a very radical opposition to the modern world. According to Evola, in primordial times or the golden age, society was a harmonious unity of four castes or classes (clergy, warriors, merchants or bourgeoisie, and servants or proletarians). Their hierarchical distinction was "neither political nor economical but spiritual," says Evola. At the apex of this pyramidai society was the king-pontifex (etymologically, the maker of bridge, pons, pontis), bridging the two realms of the world, the "becoming" of the physical world and the "being" of the metaphysical dimension. The metaphysical realm is the "spiritual-world above and beyond that supports the inferior-material-world and it is the real principle of life." According to Evola, back in remote prehistory, the rise of rationalism, which separated philosophy from religion or reality from myth, broke the harmony of the castes and the unity of the two realms: thus the "involution" of modernity began. Under the attack of rationalism the world's order, the "Tradition", slowly disintegrated. The main phases of this process of disintegration are the rise of Christianity undermining the Classic Greek-Roman world, the communal civilization, and the Renaissance and Reformation, which destroyed the Middle Ages. In this process, according to Evola, the hegemony passed down from the religious caste to the warriors and from these to the third estate or merchants. The last leg of this "regressive" march 
These ideas mediated through the periodical Ordine nuovo (and perhaps through the reading of Evola's books including Rivolta contro il mondo moderno) circulated among some Italian right-wing radicals like the comrades of Toronto's Italia d'Oltremare, who were in contact with the Evolian youth movement $O N$, as the leaflet documents. The very title of the Toronto periodical Tradizione echoes the key word in Evola's anti-democratic conception of history and man and distinguishes it from Rivolta ideale. A further distinction is that in Montreal, a hard core fascist nucleus (veterans of the Petawawa Internment camp, 1940-1945, like Gentile Dieni, one of about twenty Italian Canadians who voluntarily enrolled for the fascist invasion of Ethiopia in 1935-36) had been present there all along. ${ }^{42} \mathrm{New}$ immigrants to Montreal, such as De Cecco, gave this hard core nucleus a fresh start, which was strongly marked by anti-Semitism. In Toronto, on the other hand, neo-fascists were, as far as one can tell, all newcomers who averted the gross anti-Semitism of their Montreal counterparts.

The first issue of Rivolta ideale was eight letter-size sheets printed on one side only and stapled together. At the beginning, the periodical was divided into two parts: the first part, pages one to four, was edited in Montreal while the second part, pages five to eight, was edited in Toronto. In every issue in our possession, each page edited in Toronto carried a slogan, popular with fascist veterans. For example, on pages five and six the slogan reads, "Even if all others fail we keep faith to (or by) ourselves;" on

was the French Revolution, which opened the door to the fourth estate, the servants, with democracy and communism.

Confusing technical development with progress, modern Man has, Evola argues, slowly alienated himself from the metaphysical or spiritual realm. Integrating and mixing social castes and races, modernity has destroyed the metaphysical order, creating an undifferentiated society and impure races of bastards. This social and racial chaos is today embodied in both, liberalism and its democracy and socialism and its ultimate development communism. Consequently Western Man has totally lost his divine origin and his "spiritual" and "heroic dimension." Man has become the one "dimensional," materialistic "homo oeconomicus." Odd as it occurs, starring from opposite premises than Evola, Herbert Marcuse of Frankfurt School arrived at the same conclusions. See his One-Dimentional Man. Evola's "revolt" against modernity implies, then, a return to "Tradition," pyramidal society, by returning to the spiritual value of the castes and the differentiation and purity of the races. However, races should not be understood in the "scientific-biological" sense, which, according to Evola, are only "idols of nineteenth-century Positivism."

42 See Principe, The Darkest Side of the Fascist Years, 71; Bruti Liberati, "The Internment of Italian-Canadians," 76-98. 
page seven it reads, "cowards and servants are not ... [a word is illegible] to God," on page eight the slogan is, "our honour is called loyalty." This was coined on the basis of the Nazi motto, "SS man, your honour is your loyalty" which, according to Evola, echoes an ancient Saxon maxim, "Every honour derives from your loyalty." 43 In tune with the slogan, the content of the articles edited in Toronto often contrasts and compares the loyalty of fascists with the betrayal of anti-fascists.

In the subtitle, Rivolta ideale declares itself to be an "anti-communist Italian workers' paper dedicated to the struggle against international bolshevism and all those forces that postulate the end of races, nations, and Christianity. It stands for the triumph of the fundamental principles of nation, state, justice, and fatherland (Patria)." The Italian Canadian neofascists both in Montreal and Toronto emphasized their loyalty to the Patria. In the article "Idee e programmi" (Ideas and programs), which might be considered their ideological and political manifesto, they emphatically state what they call their "new revolutionary vision of the world." Echoing Evola's ideas, their world is "antagonistic to the present capitalist-Bolshevik society." They then go on to explain what this new vision of the world entails and what they stand for; namely 1) "... a stern and disciplined society, purged of its democratic, decadent and laughable attitudes;" and 2) "a society based on the authority of the state-the state should guide the national community, a community of blood." 44

In synthesis, Rivolta ideale stood against democracy, bolshevism, Judaism, Freemasonry, and blacks whose objective had been, according to the periodical, to drain the strength and undermine the leading "role of the Aryan race." From the first issue on, its editors expressed their racist ideology clearly and without ambiguity: "We want and we prepare a 'NEW ORDER' for all nations of the white race. We want the individual to be conscious of himself and of his duty to the national community." Again echoing Evola's views they say, "We do not want him [the individual] to be a number or a machine as democracy and communism conceive him to be. We fight against all those international powers that for centuries have tried to destroy Christian unity, the concept of Patria, and loyalty to race." 45 Moving beyond nationalism, the editors' concept of loyalty had expanded to include race.

True to its anti-Semitic program, Rivolta ideale published a long two-

${ }^{43}$ Germinario, Razza del Sangue, 34.

${ }^{44}$ Rivolta ideale 1.1 (Oct.-Nov. 1964): 3.

45 Rivolta ideale 1.1 (Oct.-Nov. 1964): 2. 
part article by the editor Vittorio De Cecco, reviewing Giovanni Preziosi's life and work. An excommunicated Catholic priest, Preziosi was the most infamous among Italian supporters of anti-Semitism during the fascist era. He saw Jews plotting against Italy everywhere, even among the leading core of the fascist party, in which he was isolated and despised by almost every one. For example, the most extreme and anti-Semitic leader, Roberto Farinacci, described his collaborator Giovanni Preziosi, as "an integral racist but a filthy Jew in his soul." 46 Preziosi enjoyed some macabre prestige during the second phase of fascism, the fascism of Mussolini's Italian Social Republic, which was created and dominated by the Nazi army occupying Northern Italy. When on 25 April 1945, partisans freed Milan, Preziosi and his wife jumped to their death out of their apartment window.

The apologetic articles reviewing Preziosi's life conclude with the following statements: "In his [Preziosi's] name we are going to establish a course in racism [racial knowledge] and social politics; a course which will be given to our members in the future" and "a club of revolutionary policy, now under study by our youth group, will be constituted and named after him." ${ }^{77}$ In another issue of Rivolta ideale, the editor De Cecco reviews the thought of Alfred Rosenberg, the leading official Nazi theorist of the Aryan race's superiority, 48 giving a European reading of Rosenberg's strictly pan-German view of the Aryan race. Furthermore, De Cecco criticizes the Roman Catholic Church for charging the Nazi revival of pre-Christian religious rites as "pagan": "The Church calls pagan these socio-political phenomena. According to us this is not exact. It would be better to call them with their proper name, returning to the origin: SOLAR CULTS were celebrated one millennium before Christ. They are not 'evil' as the Church makes its faithful followers believe. They are manifestations of a mystical religion, adoring the Divine Being dominating the Cosmos." 49

Eventually the collaboration between the Toronto and Montreal neofascist groups came to an end, although it is not known exactly when or why. ${ }^{50}$ Perhaps the Toronto group was not ready to follow the crude and unarticulated racist stand taken in Montreal. Perhaps they believed in a

46 Roberto Farinacci, quoted by Giorgio Bocca, La repubblica di Mussolini, 205.

${ }^{47}$ Rivolta ideale 5.5 (May 1968): 5.

${ }^{48}$ Rivolta ideale 7.1 (Jan.-Feb. 1970): 6-7.

${ }^{49}$ Rivolta ideale 7.1 (Jan.-Feb. 1970): 6.

${ }^{50}$ Unfortunately Stefano Sinicropi, who could explain the end of the collaboration, is severally sick and has lost his memory and lucidity; and De Cecco died recently. 
more refined form of racism, the racism of the soul formulated by Evola. ${ }^{51}$ Another important difference between the two groups was that in Montreal, Unità italica had contacts with other non Italian right-wing extremist and racist groups, 52 while, as far as one can tell, Toronto's Italia d'Oltremare confined its activities and contacts within the Italian community. 53 At the same time, Toronto's young and more mature right-wing militants of Italia d'Oltremare began to publish their own periodical, Tradizione, in 1970. Its subtitle reads: "Internal Monthly Bulletin of the Traditionalist Cultural Centre 'Italia d'Oltremare'." Even Tradizione was produced with the same parsimonious means initially used for Rivolta

${ }^{51}$ In ending his "Appunti sulla morfologia spirituale. Analisi dell'anima ebraica," Evola wrote: "Specie in fatto di dissociazioni interne, di labilità, di mancanza di dirittura e di forma interna, è evidente che si tratta di fenomeni che, purtroppo, non sono limitati all'elemento ebraico, ma che anche molti esponenti della umanità detta 'aria' presentano, e ai nostri giorni più che mai. Così dovrebbe essere nostra massima colpire l'Ariano 'ebreo' prima dell'Ebreo tale per razza e per destino; combattere l'Ebraismo come una possibilità negativa latente anche nell'uomo non ebreo e capace di emergere e di predominare in ogni periodo di crisi, prima di portare unilateralmente l'attenzione sull'Ebraismo che si incarna in uomini di determinata razza del corpo," Evola, Testi di 'Ordine Nuovo,' 43.

52 For example, under the title "Le nostre attività," we read, "sabato 18 marzo 1968, nella locale Casa d'Italia, I'Unità Italica ha commemorato la data del 28 marzo 1919, in quell'anno venivano fondati a Milano, in Piazza San Sepolcro i "Fasci di Combattinento" da Benito Mussolini. Alla cerimonia erano presenti i membri dell'associazione, più alcuni camerati Ungheresi, Canadesi e Rumeni. Il Capo dell'Unità Italica V. De Cecco ha illustrato in un breve discorso il signifcato della storica data. Il Prof. Emile Mircea Horia, ex appartenente alla Guardia di Ferro Rumena, ha poi presentato e commentato il suo libro di recente pubblicazione, Restauration chrétienne nel quale egli denuncia le infiltrazioni marxiste e massoniche nella chiesa di Roma." Rivolta ideale (May 1968): 8.

53 On Sunday, 29 July 1973, the Western Guard Party invited Italians to attend a commemoration of Mussolini's birthday. As far as we know (we were demonstrating there, at 260 Ashdale Avenue) no Italian attended that rally. The Western Guard distributed a leaflet announcing the meeting. It was headed with the words IL DUCE in solid large letters and bore a photograph of Mussolini among his comrades. The photograph was framed between two large fasces. The caption under the picture reads, "Domenica 29 luglio 1973. The Western Guard Party organizzia [sic] un ricevimento in onore del compleanno del Duce. Tutti gli interessati sono cordialmente invitati al 260 di Ashdale Ave. Sarà servito un rinfresco gratis. Per informazioni chiamare 466-3446. Prezzo d'ingresso \$2.00.” Except for the word organizzia, an obvious typographical error, the Italian language of the announcement is correct and that of a native speaker. 
ideale: a duplicating machine and legal-size sheets stapled together. The editor was Stefano Sinicropi, assisted by Antonio Iozzo, then a university student, and Domenico Capotorto.

Although it shared the same ideals professed by Rivolta ideale, Tradizione was more refined in presenting its program and its goals, which were, according to its editor(s), solely cultural and directed to the membership of Italia d'Oltremare and its supporters. As mentioned, Tradizione did not foster the gross anti-Semitic and anti-racial slurs or the brash arrogance displayed by Rivolta ideale. For example, the contents of the first issue included a poem by the French poet Robert Brasillach who had been executed by the French resistance, a review of Evola's book Lo yoga della potenza, a note commemorating the fascist philosopher Giovanni Gentile, and an historical page, "Idi di Marzo," about the betrayal and assassination of the Roman Emperor Julius Caesar. However, the ideological basis of the group Italia d'Oltremare is best expressed in two short articles, "Tradizione" and "Precisazione."

In the first piece, which defines what they mean by the word "tradizione," the Evolian concept is tied to a sense of hopeless stoic resignation:

For us tradizione is not an empty word detached from the reality of the modern world. It is a powerful force, which has, throughout the centuries, been embodied in highly civilized Republics, Monarchies and Empires. The essence of tradizione that we refer to is a spiritual conception of life and world in which Man is not considered only in his immanent existence but as a being belonging to a transcendental dimension (a religious dimension). In this dimension, Man has the power to ascend to the highest peak of his interior boundless potential ([these men were considered] semi-gods in the Orient, heroes in Greece and Rome, Saints for the believers, great artists and statesmen [today?]).

It follows that an essential element for the man of "tradition" is his life style, that stern way of life, which in the Roman Empire was shared by all, from the Emperor to the humble citizen of Rome (Urbe).

The Modern era, characterized by the psychosis of naturalistic egalitarianism, has lost the vision of those principles and the possibility of their return is illusory.

In the last hundred years, a swelling tide, which has been defined as progress, smashed, in the last World conflict, the residual resistance of the last rebels (Italy, Germany and Japan); and the tide has become uncontainable.

To appeal to the tradizione today is the last and extreme attempt to recreate that [stern] life style, which made the ancient empires great, in an Elite whose major achievement shall be to resist the egalitarian world in dissolution. ${ }^{54}$

${ }^{54}$ Tradizione 1.1 (March-April 1970): 1; in a note titled "Riflessioni," Sinicropi restates this argument in Il faro 1.1 (31 Dec. 1971): 10. 


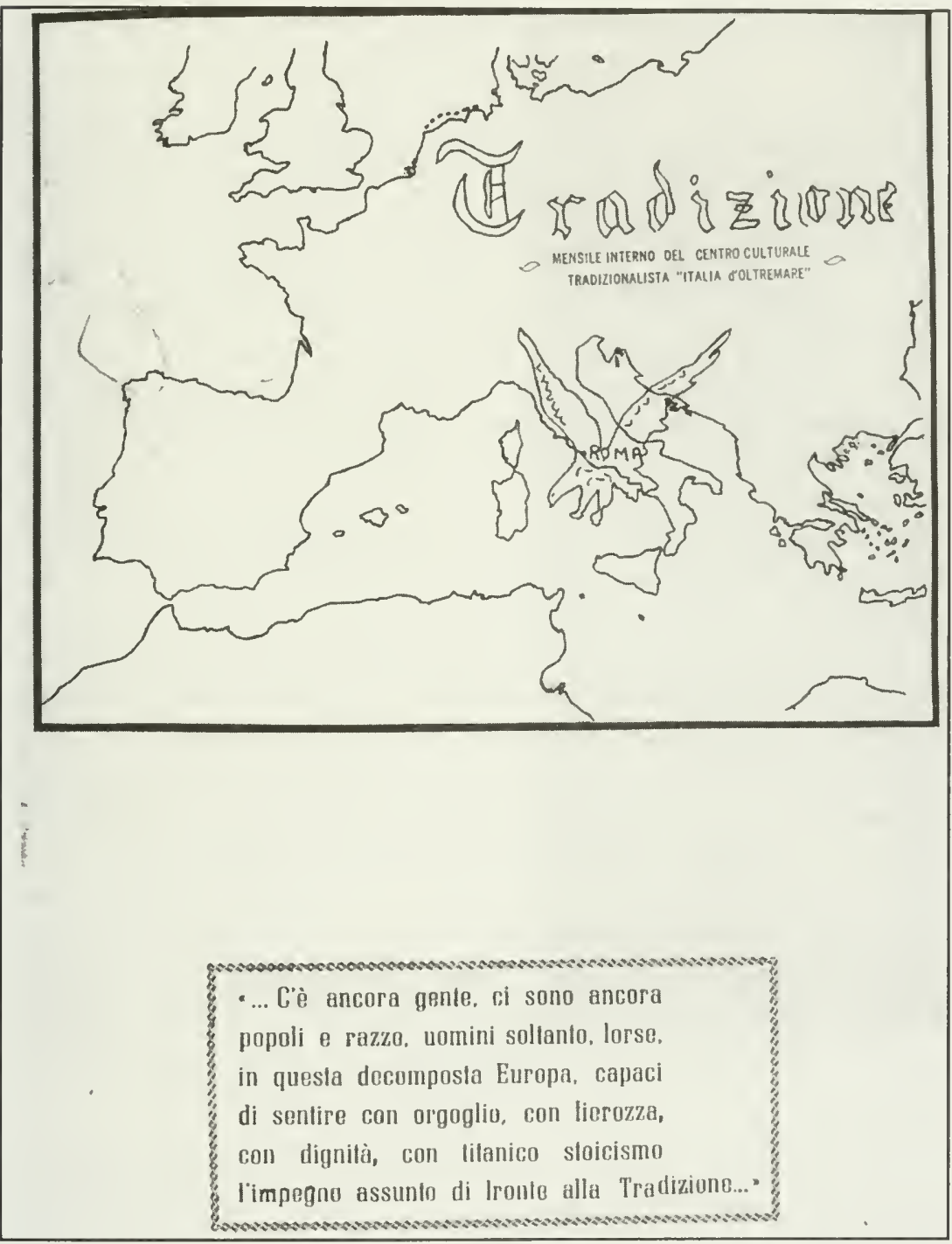

Certainly stated unintentionally, the phrase, "the possibility of their return is illusory," is perhaps the most destructive criticism ever inflicted on Evola's esoteric conception of "tradition."

The second piece, "Precisazione," states Italia d'Oltremare's reaction to the news that Pino Rauti and some other leaders of $\mathrm{ON}$ had re-joined the MSI. True to Evola's teaching, the Toronto radical activists' opposition to and rejection of modernity was total: once again their stoic despair and sense of defeat dominate the written page as they maintained that corrupted democracy had "submerged everything." Signed by Stefano 
Sinicropi, the piece reads:

to those who repeatedly invite us to continue our struggle under the Flame [symbol of the MSI] and within the M.S.I. [sic] rather than continuing our sterile struggle alone, we reaffirm our ideas: our struggle is against the system. Since the M.S.I. has definitively set itself within the demo-party system [note the ambiguity of the truncated word 'demo', which might stand either for democratic or demonic or both], we have no use for such a party. In this particular moment when the democratic flood has submerged every one, and even many comrades of the executive of Ordine Nuovo have given in and re-joined the M.S.I., there is not much left for us to do except to be loyal to our ideals: we continue on the way indicated by those who sacrificed their life for the idea. ${ }^{55}$

However, not all the members of Italia d'Oltremare shared Sinicropi's views since the Association and even Sinicropi himself became involved in promoting Il Faro, as we shall soon see.

Neither Rivolta ideale nor Tradizione, the latter more than the former, had any interest in Canadian public life or community affairs. The problems of Italians in Canada were ignored. The discussion on the future of the world (which was supposed to be a new social order with the Aryan race as its leading mind and engine) was so abstract that it seemed a tribal, rather than a universal view of the world. One can argue that this was a sign of their alienation from communal life, a state of mind common to many Italian immigrants, as noted above, and an indication that there was no Canadian political party for them to dialogue with. However, true to their word and beliefs, some of the men involved in publishing Tradizione remained an example of the probity and the stern and anti-modern and 'decadent' way of life they preached: the siren song of riches had no allure for them.

The comrades of Montreal did not share the stoic stand of Toronto's Italia d'Oltremare and approved the use of violence against what they considered the communist aggression of Italy. Echoing like-minded Italian radical fringes, Rivolta ideale supported Italian right-wing groups meeting the communists on their own ground, violence with violence: "While all shades of Marxists elaborate plans and act to dominate the World and the weak Nations [...] the right-wing forces are wasting time in long discussions and useless polemics on what to do! There is too much talking in Italy," lamented Rivolta ideale. Then it goes on to state that, "It is necessary to act, to do

55 Tradizione 1.1 (March-April 1970): 3. 
something. Be politically and ... also militarily ready! [...] our reader has already understood what we allude to and what we mean when we say being ready to act. We don't need to spell it out in detail. [...] If communists are organizing armed bands under the instruction of Albanian and Chinese agents on our national territory [...] we should not twiddle our thumbs (stare con le mani in mano) waiting for the Messiah to save us," it concluded. ${ }^{56}$ But Italian right-wing militants did not need to be incited by Rivolta ideale. They did not wait for the Messiah: according to Ugo Pecchioli, "from 1969 to 1975 there were 4,384 acts of political violence in Italy, with 83 per cent of them committed by neo-fascists." 57

While this wave of neo-fascist violence shook the democratic system in Italy, the monthly Il faro appeared in Toronto at the very end of 1971 (December 31). With this publication, the neo-fascist presence was felt in the Italian communities in Canada, ending the almost clandestine existence of Rivolta ideale and Tradizione. Skilfully edited by Giuseppe Derin, Il faro, a tabloid-size monthly, was financed by the MSI, which hoped eventually to harvest votes if Italian citizens abroad were to be given the right to vote abroad for elections in Italy, as eventually happened in 2002.58 In the first issue of Il faro, Derin listed an impressive roll of reputed rightwing journalists as his collaborators from Italy. It included staff writers of Il borghese, an ambitious conservative monthly magazine, and at least one anti-parliamentarian, Giorgio Pisanò, the leader of the revolt of Reggio Calabria and editor of a most radical monthly titled Candido. ${ }^{59}$ As correspondent from the United States (though retired in Switzerland) was none other than Giuseppe Prezzolini, who had been the editor of the prestigious periodical La voce (1908-16), past director of the Casa Italiana at Columbia University, in New York, and author of several books.

${ }^{56}$ Rivolta ideale 5.5 (May 1968): 7.

${ }^{57}$ Drake, "Julius Evola," 89.

${ }^{58}$ It was said in the community that for the publication of $I l$ faro, the Toronto neofascists received over $\$ 50,000.00$ from the MSI, but we are unable either to confirm or deny this allegation.

${ }^{59}$ In its first issue, Il faro published a full-page article by Giorgio Pisanò, titled "Popolo Bue Svegliati" (Wake Up, Dumb Oxen); p. 9. The article is a violent, verbal diatribe, against everyone and everything. He repeated his despicable charge against Giacomo Mancini, the leader of the Italian Socialist Party, calling him a "thief." Ten years later, after a long court case, the court exonerated Mancini of that vile charge, but in 1972 it cost him the leadership of the Party, being replaced by Francesco De Martino. In Mancini's defense see Cozza, Tecnica di un'aggressione. 

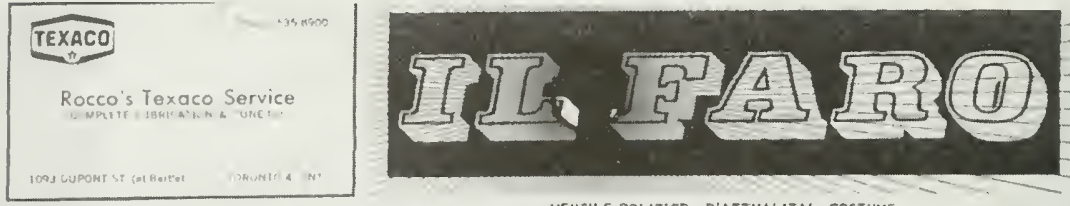

Anno 1 No 1 - Toronto Canada! $\$ 10$ cenbre 197

\section{Salve, amici lettori!}

ESCLUSIVO IL CONSOLE GENERALE ANGELETTI: dral SONO UN PROEETA POPOLO BUE, SVEGLIATI!

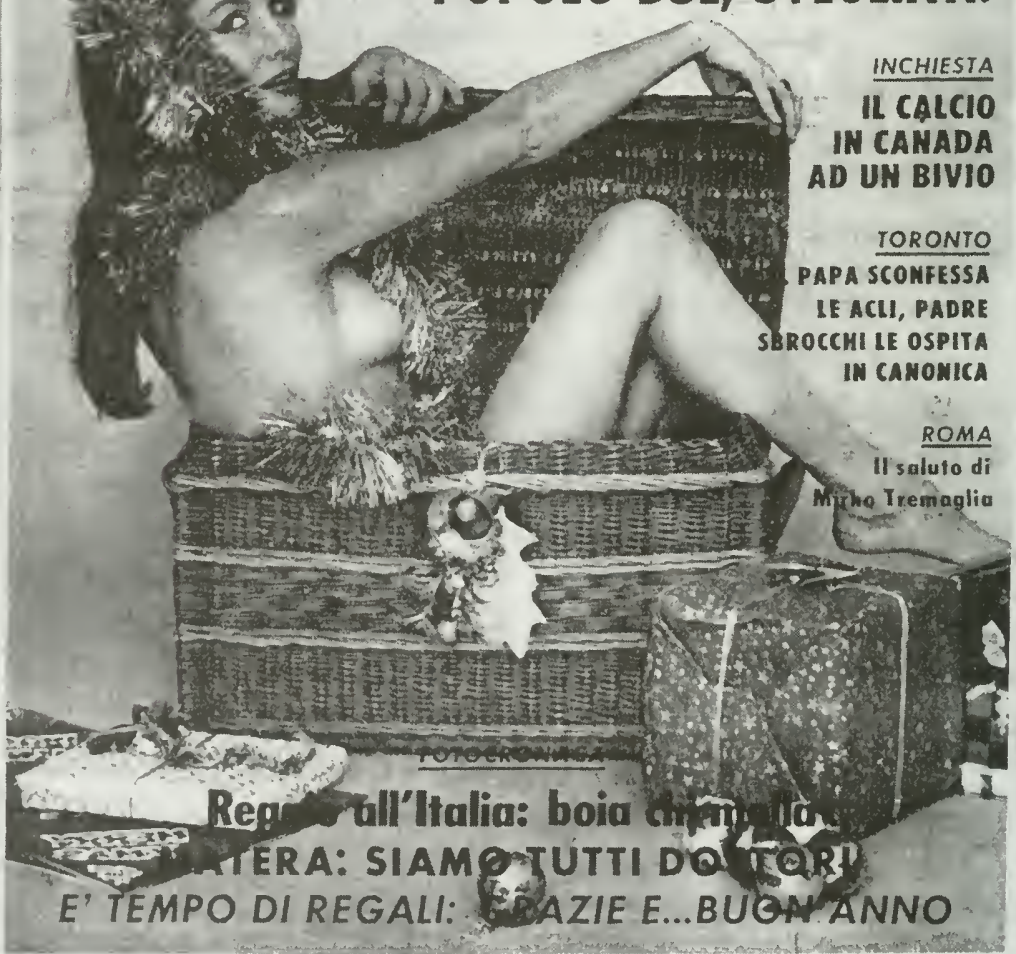

Il faro was the fruit of collaboration between the two Toronto right wing groups: Italia d'Oltremare and a new neo-fascist group Comitato tricolore per gli italiani nel mondo (CTIM), which was organized and headed by Giuseppe Derin, an ex fascist. The CTIM was the MSI's worldwide association headed by Mirko Tremaglia, a veteran of the RSI, and now (2004) Minister of Italians Abroad in Berlusconi's second government. The editor 
in-chief was Giuseppe Derin, assisted by Vittorio Coco. The other members of the editorial board were Alberico Alberici, Giorgio Orla, Attilio Cubbeddu, Giovanni Declario, Domenico Capotorto, and Stefano Sinicropi. Il faro's local editorial board, made up of members of the two neofascist associations, confirmed their uneasy accord and, could be said to reflect the re-joining of the youth movement ON with the MSI in Italy. The editorial published in the first issue confirms the ideological compromise reached between the two groups. The repetition of the word tradizione makes this point clear: "besides bringing to mind the traditional lighthouse at the entrance of harbours, the masthead Faro is also a symbol of the tradition to which, in a world in decomposition, some nations, races, or perhaps even individuals sensitive to spiritual values, may look for guidance as navigators, sailing in darkness, look to the lighthouse." 60 [emphasis added]

The editorial (which is an invective against democracy and communism as accomplices in the destruction of human values) never mentions fascism or the neo-fascist MSI. It leaves no doubt, however, that Il faro is a neo-fascist paper as the following passage makes clear: "We feel that our primary task did not end with the military defeat in 1945. Because, while everything around is chaos, the real problems remain unsolved, and moral decadence is becoming more pronounced, not for one moment have we doubted that we would once again be useful to Western civilization."61 And in the note, "Appello ai nostri amici di Toronto" (Appeal to our friends in Toronto), one can read, "regarding its [the paper's political] orientation, there is no need to waste words. It is evident, isn't it?"62

Breaking with the isolation of previous right-wing publications, Il faro devoted some space to the problems plaguing the community, making the paper relevant to Italian Canadian readers regardless of their political orientation. The demise of this monthly is to be attributed to a mesh of different factors: financial, political, ideological, and personal problems. The spark that destroyed the precarious unity was this: one individual, [...], misappropriated for his personal use money from the group's funds. To avoid what they considered a scandal that would reflect negatively on the entire group, they did not call the police. But their collaboration became impossible. 63 This episode caused the latent ideological conflict between

60 Il faro 1.1 (31 Dec. 1971): 3.

61 Il faro 1.1 (31 Dec. 1971): 1.

62 Il faro 1.1 (31 Dec. 1971): 2.

63I learned this from conversations with some of the people involved with Italia d'Oltremare and the publication of Il faro (Berlinger, Capotosto, and Mastrangelo). 
the politically oriented neo-fascists of the MSI and the uncompromising Ordinovisti, compounded by personal rivalries and financial difficulties, to explode. Since the financial support from Italy did not cover all expenses, the economic burden became too great for the few supporters and their shaken unity, thus destroying their hybrid child, Il faro.

Not long after the end of Il faro, Occidente appeared. This new monthly was Derin's offspring in every sense: it reflected his personality and his prudish intolerance, mirroring the above mentioned Roman periodical Borghese that Derin was so fond of. Nevertheless, there are several interesting differences between these two neo-fascist tabloids. Occidente did not have the impressive list of collaborators that Il faro boasted. Further, the scorching ideological criticism against democracy, characteristic of sectarian neo-fascist publications, disappeared from the pages of Occidente. The space devoted to events and problems in the Italian community was expanded, although it consisted of only 16 pages while Il faro had had 28. More importantly, Occidente translated its key articles into English in an attempt to reach the new generation of Italian Canadians and probably some of the non-Italian conservatives. In the 1975 Ontario's provincial election it supported the Progressive Conservative Party and some of its candidates advertised their name with paid ads.

Like Il faro, Occidente was a lively, though at times, waffling journal. It engaged in polemics with all the Italian Canadian publications: Forze muove, Il Corriere canadese, Mosaico, Il giomale di Toronto, Il samaritano, and even with CHIN Radio. Though forceful and sharp, it never went beyond a fierce urban polemic with its political adversaries. Occidente opposed multiculturalism. Upholding a strong all-centralizing state, it could not understand an open society like the one sought and explored by Canadian multiculturalism. As a conservative newspaper it singled out and stood against what were considered the evils of modern, decadent society: women's liberation, homosexual rights, abortion, sexual education, and so forth. The editor could not understand that his dream of an old, nineteenth-century repressive society was disappearing. In an editorial that sounds like an instigation to violence, he wrote:

Two are the roots of man on this earth: Family and Country. The first is consecrated by all the sentiments and all the aspirations of our entire being; the second is the sense of the nation-state, the total sum of all the historical and cultural experiences of a people. In the world of today the hour has certainly come to take up the cudgel in their defence. International and incessant is the struggle, because international and frightful is the enemy, Communism. ${ }^{64}$ [emphasis added]

${ }^{64}$ Occidente 1.1 (1 Apr. 1975): 2. 


\section{OCCINENTE}

ETNA GIFT \& RECORD

CENTER

42 DA VIOHTH AYF TOROSTU, UNTARU

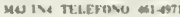

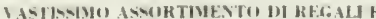
HUMUMUER PER TETTE LE UCCANIONI

\begin{tabular}{|c|c|c|c|}
\hline A18w: & 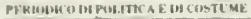 & - OTTUERE IV7s - & ABCUSU CLUSS MALE So sem \\
\hline
\end{tabular}

\section{L'ONORE D'ITALIA}

\section{F

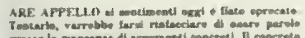

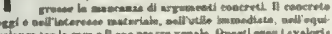

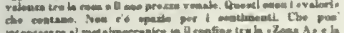

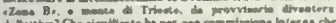

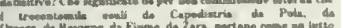

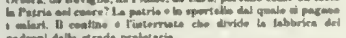

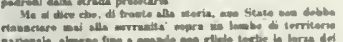

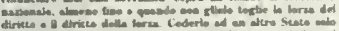

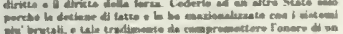

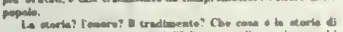

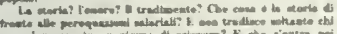

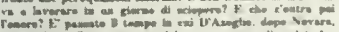

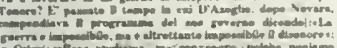

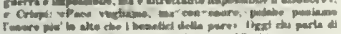

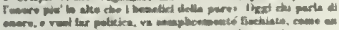

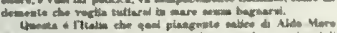

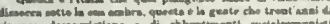

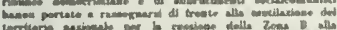

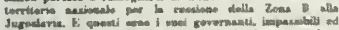

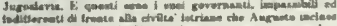

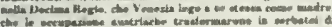

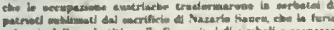

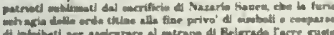

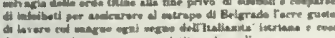

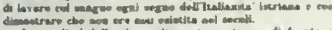

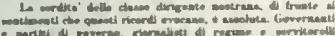

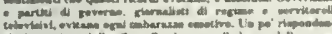

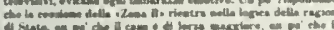

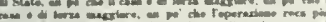

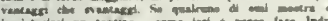

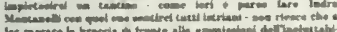

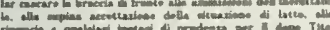

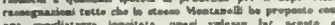

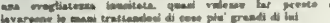

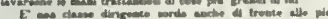

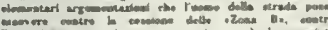

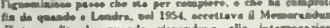

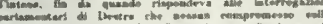

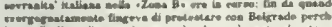

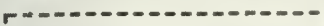

MISSIONE H AL.MLRANTE

ALLA CASA BLANCA

PMint i-8-4)

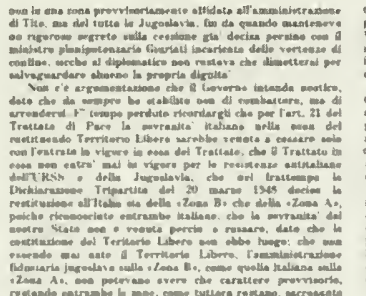

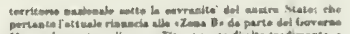

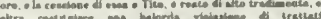

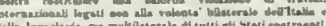

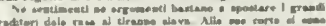

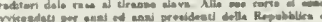

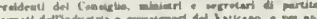

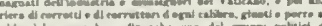

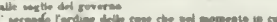

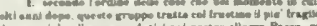

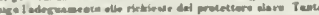

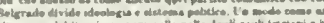

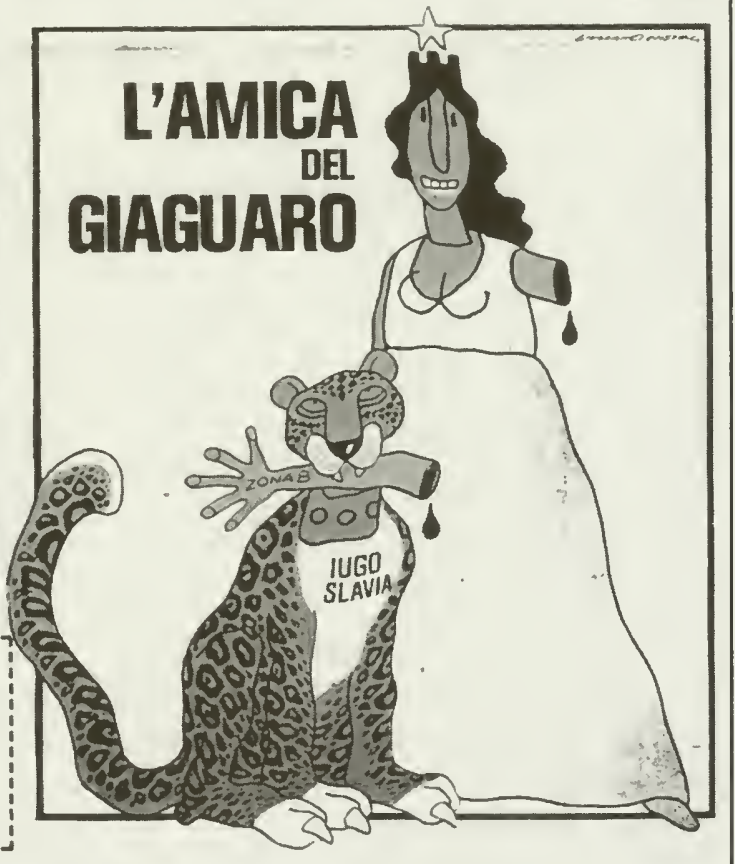

Clearly Occidente and its editor mutilated the old triad of God, Country and Family, by leaving out God: a state of affairs interestingly at odds with traditional conservatism. Changes had infiltrated even the conservative, neo-fascist citadel: the editor wanted to stop social changes, although he was not even able to stop the change that had invaded his own conscience. 
The electoral success of the MSI in 1972 was received with euphoric enthusiasm by local neo-fascists. In a leaflet distributed in Toronto, celebrating the "VITTORIA TRICOLORE", local missini (neo-fascists) wrote:

Ever since that day when a great dream ended in the blood of betrayed fighters, we have been waiting for a new day. We have felt the pain of defeat and the humiliation of insult, but we stood strong because we have been certain that, although everything was crumbling around us, as a consequence of that ruinous night, ${ }^{65}$ a new day would come for Italy and Europe. And we have waited patiently all these long years. We have waited for a signal, a song, or echo of a stamping foot breaking the silence of the night as a promise of redemption. We have waited either for Italy to find her face and soul or for the Italians to find an idea and a flag. Finally, from noble Sicily, from Rome, Bari etc. comes the first spark, the first promise of recovery and redemption. Italians have found, once again, the eternal value of their civilization by rallying behind the Movimento sociale italiano.

The future is now ours. 66

The June 1976 election in Italy and the Ontario election in September of the previous year (in which four Italian Canadian socialists, Odoardo Di Santo, Tony Grande, Tony Lupusella, and Ross McClelland, had been elected to Queen's Park) created conditions profoundly different from those existing on both sides of the ocean in the early 1970s. The resounding victory of the communist party and the crushing defeat of the MSI in the 1976 national election in Italy, which provoked a serious split in the neo-fascist party, ${ }^{67}$ dashed all the hopes of the right-wing leaders and extinguished the enthusiasm of local militant neo-fascists. It was the beginning of the end for the neofascist press in Ontario, although it agonised for two more years.

${ }^{65}$ It is not clear to which "night" the writer refers. Perhaps 25 July 1943 , when the Gran Consiglio Fascista approved a motion to give the king the legal power to dismiss Mussolini and order his arrest; or perhaps it might refer metaphorically to the long wait in political limbo; or some other unknown event.

${ }^{66} \mathrm{~A}$ "Speciale: Elezioni Italiane '72" issue of Il faro 2.5 (31 May 1972) was printed. In an exulting tone, the editors discussed in detail the electoral success of the "Destra nazionale." From this issue on, Il faro and then Occidente avoid using the word Fascism or MSI and refer to it as the "Destra nazionale."

6717 out of 35 Members of Parliament, 9 out of 15 Senators, 13 out of 40 Regional councilors, 51 out of 160 Provincial Councilors left the MSI and founded Democrazia nazionale (National Democracy). 
No one regretted the termination of these publications. Since they had had no political party in Canada to dialogue with, their impact on the community was negligible. They were faithful followers of a "religion without a church." Rivolta ideale and Tradizione had a very limited readership of fewer than two hundred persons all together in Montreal and Toronto with Montreal commanding the largest portion. Il faro and Occidente mustered a larger readership because of their appeal to nostalgia for the country of origin and to anti-communist sentiments in tune with both Canadian politics and Italian Catholicism. When, soon after, Giuseppe Derin died and Occidente folded, only very few Italian Canadians noted their passing.

\section{Conclusion}

This cursory analysis of the Italian Canadian radical press has shown that the entire political spectrum was fully represented, from the extreme left to the extreme right. Political and social events in Italy and in the international sphere impacted on the condition of Canada's Little Italys, stimulating ideological reactions and political initiatives among Italian immigrants. Besides their obvious ideological differences, the basic and most important distinction between the left-and the right-wing publications was the way they perceived themselves and Italian immigration to Canada, and this in turn stimulated their political activities and conditioned their relation with and within society at large, reinforcing their respective ideological orientations.

The left-wing activists viewed Italian immigration to Canada as permanent. Hence, they felt that Italians, being neo-Canadians with the privileges and duties of every other citizen in the land, should get involved in improving the Canadian way of life for they considered Canada their own and, above all, their children's country. Their papers were essentially created in response to the economical and social conditions existing in the immigrant community, even though initially they framed local conditions within their originally Italian cultural and political experience.

Il lavoratore, the first radical paper to appear on the Italian Canadian scene in the period under examination, mirrored the social conditions on site as well as the political alignments in Italy. Local collaboration between socialists and communists of the Gramsci Club paralleled the "united action pact" existing in Italy between the socialist and communist parties during and for some years after the Second World War. Socialist-inspired periodicals, La parola, Forze move and Avanti! Canada, were interested mainly in the immigrant workers' problems and in Canadian politics; their link with the Italian Socialist Party was tenuous and mainly cultural. It can 
be argued that, in a certain way, these publications reflected the Italian Socialist Party ending the "united action pact," regaining its political independence, and entering, in a subordinate position, into the government circle with the Christian Democratic Party.

La carota, a scathing periodical with a quasi anarchist matrix unleashed its stinging criticism within the Italian community and, one might say, reflected the local and international student movement of the late $1960 \mathrm{~s}$ and early '70s. On the other hand the orthodox communist Lotta unitaria and the reformist Nuovo mondo mirrored the fracture of Italian and international communism that emerged after Nikita Krushchev's shocking revelations at the XX Congress of the Russian Communist Party and the brutal Hungarian invasion of 1956. These publications were all, each from its ideological perspective, keenly and mainly interested in the economic and social problems of Italian immigrants.

The right-wing activists and their publications took an opposite stand. For them nationalism and loyalty to Italy was paramount-these determined their perception of Italian emigration to Canada and consequently their personal stand and editorial policy. The right-wing editors thought of themselves and of the immigrant community in general as Italians abroad, working in a foreign though hospitable country: "I have changed sky, not my soul" was the slogan appearing on the masthead of Tradizione. What happened in Italy was therefore of primary importance to them, while Canadian events were of marginal or of no interest at all unless they related directly to what was happening in Italy or in the international sphere of East/West confrontation.

Rivolta ideale was an anti-Semitic and racial publication with its ideological roots in the most extremist group of Mussolini's fascist republic in Salò. The crude anti-Semitism of Rivolta ideale vanished from the other three newspapers: Tradizione, Il faro, and Occidente. While Rivolta ideale and Tradizione were both parochial bulletins ignoring completely the problems of Italian Canadians, Il faro and Occidente were full-fledged newspapers open to problems facing the community. They too were interested mainly in what was going on in Italy and shared with their predecessors a visceral form of anticommunism and a marked social conservative stand. Most of their readers and supporters were mainly people who, for whatever reason-professional or sentimental-failed to integrate or resisted integration in the new country. There were however some potential allies, like pre-war emigrants and second-generation Italian Canadians, who supported the Progressive Conservative Party, but the violent verbosity of these newspapers kept them at bay. 
The newspapers of these two groups were not monolithic. There were differences within each group and within each periodical as well. The ideas they expressed and the socio-political views they advanced were as diverse as the individuals involved within each publication and within the changing context of the Little Italys in Canada in which they operated. In the long run, however, the right-wing publications and their local organizations bore little fruit while the left-wing newspapers and their organizations left a more permanent mark on the life of the community as the results of the recent Canada-wide election for the "Comitati degli Italiani all'estero" (Comites) prove. Comites are local consultative organisms, which the Italian government recognizes as legal representatives of its citizens abroad. The election for the Comites was held for the first time ever in Canada in the Spring of 2004. The centre-left coalition won in every one of the four Italian consular areas: Montreal, Toronto, Edmonton, and Vancouver. ${ }^{68}$ This also reveals that the problems which the Italian radical publications debated in the last half of the twenty century still persist today. Although the approach may be different the issues are still alive and passionately engage a new generation of Italian Canadian activists.

\section{Toronto, Ontario}

\section{WORKS CITED}

Radical Periodicals:

Left Wing:

Avanti! Canada. (monthly, June 1975-76)

La carota (weekly, January-November 1969)

Forze muove (monthly, October, 972-82)

Il lavoratore (monthly, December 1958-61)

${ }^{68}$ In the consular area of Montreal, there were 12,588 eligible votes. The victory of the centre-left coalition was overwhelming, receiving almost $70 \%$ of the votes. The centre-left list, La nostra Italia, received 8,717 votes or $69.25 \%$ of the toral, the list All'ascolto della comunità received 3,260 votes or $25.90 \%$, and the centre-right list, Viva l'Italia, came in a poor third with only 611 votes or $4.85 \%$ of the total. In the consular area of Toronto, out of 22,727 eligible votes, the centre-left list, Progetto Italia-Canada, received 10,958 votes or $48.2 \%$, the centreright coalition list, Viva l'Italia, received 10,129 votes or $44.6 \%$, and a third list, Unione Cristiana Italiani nel Mondo (UCIM), recèived 1,640 votes or $7.2 \%$. In Vancouver there was a combined list without a specific political orientation. It received 5,047 votes out of a total of 5,847 that is $93 \%$ of the eligible vore. In Edmonton, the centre-left list, Progetto Italia-Canada, won 9 out of 12 seats and the centre-right only one seat. 
Lotta unitaria (Monthly, April 1977)

Nuovo mondo (monthly, 1977)

La parola (monthly, 1963-64)

Right Wing: $\quad$ Il faro (monthly, December 1971-1974)

Occidente (monthly, May 1975-?)

Rivolta ideale (bimonthly, 1964-?)

Tradizione (monthly, 1970-71)

Other Newspapers: Corriere canadese

Corriere illustrato

Il giornale di Toronto

Polyphony

Toronto Daily Star

Books and Articles

Bagnell, Kenneth. Canadese: A portrait of the Italian Canadians. Toronto: Macmillan, 1989.

Berton, Pierre. "How ltalians Live" Toronto Daily Star (26 June 1961): 17.

Bobbio, Norberto. Destra e sinistra. Ragioni e significati di una distinzione politica. Rome: Donzelli, 1994.

Bocca, Giorgio. La repubblica di Mussolini. Milan: Mondadori, 1995.

Bruti Liberati, "The Internment of Italian-Canadians," pp. 76-98 in Enemies

Within. Italian and Other Internees in Canada and Abroad. Eds. Franca Iacovetta, Roberto Perin, and Angelo Principe. Toronto: University of Toronto Press, 2000.

Census Tract Bulletin, 1971 Census of Canada.

Colantonio, Frank. From the Ground Up. Toronto: Between the Lines, 1997.

Conte, Franco. "Nuovo mondo" Polyphony 4.1 (1982): 126.

Cozza, Michele. Tecnica di unaggressione. Chiaravalle centrale (Calabria): Frama, n.d..

Drake, H. Richard. "Julius Evola and the Ideological Origins of the Radical Right in Contemporary Italy" pp. 61-89 in Political Violence and Terror. Ed. Merkel H. Peter. Berkeley-Los Angeles-London: University of California Press, 1986.

Enemies Within. Italian and Other Internees in Canada and Abroad. Eds. Franca Iacovetta, Roberto Perin, and Angelo Principe. Toronto: University of Toronto Press, 2000.

Evola, Julius. Rivolta contro il mondo moderno. 2nd ed. Milan: Fratelli Bocca, 1951.

- Revolt Against the Modern World. Trans. Guido Stucco. Rochester, VT: Inner Traditions International, 1995.

Testi di 'Ordine Nuovo'. Ed. Renato Del Ponte. Padua: Edizione di AR, 2001.

Ferguson, Edith. Newcomers in Transition. An experimental project conducted by the International Institute of the Metropolitan of Toronto to Study the Relation Between Rural Immigrants and Toronto's Community Services, 1962-64.

Germinario, Francesco. Razza del Sangue, razza dello Spirito: Julius Evola, l'antisemitismo e il nazionalsocialismo (1930-43). Turin: Bollati Boringhieri, 2001. 
Historical Statistic of Canada. Ed. F.H. Leacy. Statistic Canada in joint sponsorship with the Social Science Federation of Canada, 1983.

Iacovetta, Franca. Such Hardworking People. Montreal \& Kingston: McGillQueen's University Press, 1992.

Murialdi, Paolo. Come si legge un giornale. Bari: Laterza, 1977.

Principe, Angelo. The Darkest Side of the Fascist Years. The Italian-Canadian Press: 1920-1942. Toronto: Guernica, 1999.

"Two Years of Social Unrest in Toronto's Little Italy: 1960-61", pp. 1-33 in Marino Toppan, The Voice of Labour: A Life in Toronto's Construction Industry. Toronto: Mariano A. Elia Chair in Italian Canadian Studies, York University, and Frank Iacobucci Centre for Italian Canadian Studies, University of Toronto, 2003.

— "The Italo-Canadian Anti-Fascist Press in Toronto (1922-1940)," in NEMLA Italian Studies 4 (1980): 119-137; reprinted in Polyphony, Bulletin of the Multicultural History Society of Ontario 7.2 (Fall/Winter 1985):43-51.

Proceeding and report (Goldenberg Report) of the Royal Commission on LabourManagement Relation in the Construction Industry, 1962.

Rao, Nicola. Neofascisti! La Destra italiana da Salò a Finggi nel ricordo dei protagonisti. Rome: Settimo sigillo, 1999.

Salvadori, Massimo. La Sinistra nella storia italiana. Bari: Laterza, 2000.

Toppan, Marino. The Voice of Labour: A Life in Toronto's Construction Industry. Toronto: Mariano A. Elia Chair in Italian Canadian Studies, York University, and Frank Iacobucci Centre for Italian Canadian Studies, University of Toronto, 2003. 